University of Louisville

ThinkIR: The University of Louisville's Institutional Repository

Electronic Theses and Dissertations

$5-2005$

\title{
The Marian and Elizabethan persecutions : how England was prepared for persecution and defended from martyrdom.
}

Mitchell Scott

University of Louisville

Follow this and additional works at: https://ir.library.louisville.edu/etd

\section{Recommended Citation}

Scott, Mitchell, "The Marian and Elizabethan persecutions : how England was prepared for persecution and defended from martyrdom." (2005). Electronic Theses and Dissertations. Paper 1289.

https://doi.org/10.18297/etd/1289

This Master's Thesis is brought to you for free and open access by ThinkIR: The University of Louisville's Institutional Repository. It has been accepted for inclusion in Electronic Theses and Dissertations by an authorized administrator of ThinkIR: The University of Louisville's Institutional Repository. This title appears here courtesy of the author, who has retained all other copyrights. For more information, please contact thinkir@louisville.edu. 


\title{
THE MARIAN AND ELIZABTHAN PERSECUTIONS: HOW ENGLAND WAS PREPARED FOR PERSECUTION AND DEFENDED FROM MARTYRDOM
}

\author{
By \\ Mitchell Scott \\ B.A., Murray State, 2002
}

\begin{abstract}
A Thesis
Submitted to the Faculty of the

Graduate School of the University of Louisville in Partial Fulfillment of the Requirements

for the Degree of
\end{abstract}

Masters of Arts

Department of History

University of Louisville

Louisville, Kentucky

May 2005 
THE MARIAN AND ELIZABETHAN PERSECUTIONS: HOW ENGLAND WAS PREPARED FOR PERSECUTION AND DEFENDED FROM MARTYRDOM

\author{
By \\ Mitchell Scott \\ B.A., Murray State University, 2002
}

A Thesis Approved on

April 25, 2005

By the following Thesis

Thesis Director 


\title{
ABSTARCT \\ THE MARIAN AND ELIZABTHAN PERSECUTIONS: HOW ENGLAND WAS PREPARED FOR PERSECUTION AND DEFENDED FROM MARTYRDOM
}

\author{
Mitchell Scott
}

April 25, 2005

This thesis is an historical examination of the Marian and Elizabethan persecutions, with special emphasis paid to the martyrologies and the anti-maryrologies of each queen. Through analysis of primary documents this project provides an in-depth look into the process of persecuting and the problems that Mary and Elizabeth both faced. What is observable are the similarities that existed between the two persecutions and the process that persecutions followed in Marian and Elizabethan England. This project compares the persecutions of Mary and Elizabeth focusing on how they prepared England for the persecution of fellow English subjects, how and why martyrdom was applied, and how Mary and Elizabeth protected their persecutions and the English public's acceptance of the persecutions from martyrdom.

This thesis focuses on the tumultuous circumstance of sixteenth century England, the power and influence of martyrdom and, ultimately how Mary and Elizabeth attempted to control and contain martyrdom. This thesis is divided into a discussion of each reign, with a focus on the primary documents defending the persecutions and countering martyrdom. The analysis of these sources illuminates the battle for public opinion and 
public support by the martyrologies and anti-martyrologies, and that the history of the persecutions would be based on the martyrological or anti-martyrological accounts. 


\section{TABLE OF CONTENTS}

Chapter

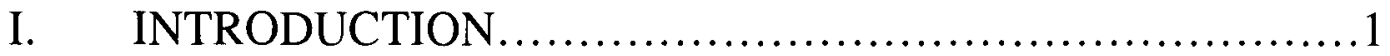

II. HISTORIOGRAPHY ....................................18

III. MARIAN PERSECUTIONS ................................40

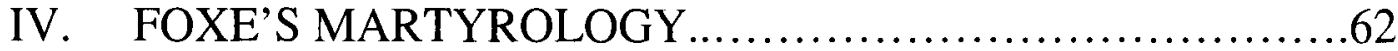

V. ELIZABETHAN PERSECUTIONS.........................75

VI. CONCLUSIONS ...........................................110

VII. REFERENCES ............................................115 


\section{INTRODUCTION}

The majority of Queen Elizabeth's subjects would have considered the year 1565 a relatively stable, peaceful and uncontroversial time. Only seven years into Elizabeth's reign, and seven years removed from the bloody persecutions of Queen Mary against English Protestantism, a religious peace had settled over England. Protestantism had conquered Catholicism with the accession of Elizabeth, and since the printing of John Foxe's Acts and Monuments in 1563, Protestantism had taken on a national identity. The controversies of Mary's reign had been concluded with the aid of Foxe and the accession of Elizabeth. The Protestant men and women executed for heresy under the reign of Mary were finally and officially glorified and venerated as martyrs. Catholicism had become a minority religion and there were no Catholic writers, at least in England, to stand in the way of these martyrdom claims or to present these Protestants as heretics instead of martyrs.

It appeared that the outcome of the debate between Protestants and Catholics had been determined with the death of Mary, the end of her enforcement of Catholicism as the dominant religion of England and the printing of Foxe's Acts and Monuments that galvanized English Protestantism. The controversy of "true" and "false" martyrs had been decided. In Marian England Protestant writers had attacked the persecutions and 
defended their faithful by presenting their executed co-religious as martyrs. Marian Catholic writers defended the persecutions by refuting and attacking the Protestants as "false" martyrs. This "false" martyr label, perpetuated by the Marian administration and furthered by Catholic writers of the reign, was finally discarded under Elizabeth. The Protestants were "true" martyrs of the Church and would be glorified presently and historically for their noble deaths.

This was not, however, a debate that would simply vanish, for its intensity would not fade with the accession of a succeeding monarch. This controversy of "true" and "false" martyrs carried with it the English peoples' perception of the events and the accepted facts of the persecutions. One side had to be remembered as criminal, whether it was Protestant heretics for their blasphemy and nonconformity, or Catholic persecutors for their brutal crusade against English Protestants. This debate would prove to be embedded within English society and in 1565 Thomas Stapleton continued the Catholic role of denying English Protestants, who died under Mary, their status as martyrs.

Seven years after Mary's death in 1558, Stapleton resumed the conflict that had raged over the nature of the Marian persecutions. Stapleton wrote from Europe as a Catholic exile of Elizabeth's accession. His writing is a prime example of the controversy between Protestant martyrologists and Catholic anti-martyrologists that had circled England during the reign of Mary. This controversy attempted to determine how those that did the persecuting and those who were executed would be defined. Stapleton's Fortress of Faith followed the guidelines set forth by his contemporaries, Marian Catholic writers and the Marian anti-martyrologists that countered Protestant claims of martyrdom. Marian writers had defined the Protestants as heretics, followers of 
heterodox beliefs counter to those of the "true" Church, and anti-martyrologies emphasized that these heretics could not be transformed into martyrs. Stapleton applied many of the same methods that Marian writers applied during the time of the persecutions by calling upon the Bible and Christian history. Stapleton presented examples of the early Christian martyrs and emphasized the lack of martyrdom qualities displayed by the Marian Protestants.

Stapleton considered the Protestants that had gone willingly to their execution, and the present Protestants of England who revered them as martyrs, to be ignorant and misguided. Protestants completely ignored the "many hundred years of the universal Church," shamelessly contradicting "any writer or authority of these late hundred years." Stapleton was astounded that the Protestants connected themselves, and their cause, to that of the early Christian martyrs. If these Protestants evangelized, as had the early martyrs, Stapleton asked, then where were the infidels they converted? Stapleton wrote that they had no such ability to minister as "false" martyrs, for their message was only intended to "pervert a good Christian."2 Stapleton wondered, if these Protestants were "true" martyrs, why had there been no miracles performed or seen? The presence of miracles was a defining aspect of martyrdom to Catholics and was "given of God to witness his holy will, to testify the faith and to warrant that which is preached." ${ }^{3}$ Without the presence of miracles, Stapleton argued that the Protestants preferred "darkness before light, they extol falsehood above truth and command idolatry over true Christianity."

\footnotetext{
' Thomas Stapleton, Fortress of Faith (London, NP, 1565), 2.

${ }^{2}$ Stapelton, Fortress of Faith, 11.

${ }^{3}$ Ibid, 12.

${ }^{4}$ Ibid, 76.
} 
In 1565 Stapleton's writings were aimed at a dominant Protestant majority of England and a Catholic minority. Although this separated Stapleton from the Marian writers and anti-martyrologists, who had defended a dominant Catholicism and attacked a Protestant minority, Stapleton's Fortress of Faith displayed the intensity of the controversy between persecution, anti-martyrologies and martyrdom. It was a controversy that vied for public opinion and support of persecutions or public death--one that would resurface in the 1580 s, as Elizabeth began persecuting Jesuits and Catholic missionaries ministering in England. It was a controversy that, once decided, would inevitably control the history of both the Marian and Elizabethan persecutions.

The Marian and Elizabethan persecutions were considerably different, but they faced similar problems and consequences. The most important and damaging of these consequences was martyrdom. Martyrdom was one of the most powerful Christian concepts that could be applied to persecution. Martyrdom, the death of a "true," pure and faithful Christian at the hands of a vengeful authority, carried with it the power and ability to destroy the persecutions by garnering sympathy and creating conversion within the public--thereby destroying everything the Crown attempted to create and pursue with its persecutions.

In order to fully understand the impact of persecutions and martyrdom upon England, it is important to grasp the religious turmoil that characterized England in the sixteenth century. From 1534 and Henry VIII's Act of Supremacy, the religion of England was driven by the religious convictions of its monarchs. Henry had officially removed the Church of England from papal control, and although this was not a complete separation from Catholicism, Protestant ideology began to emerge within England. 
Henry died in 1547 and his nine-year-old son Edward VI took the throne of England. Edward was surrounded with Protestant councilors and inevitably, the atmosphere of England evolved toward Protestantism. Edward's reign would be marked as the brief Protestantization of the English Church. Unfortunately for the budding Protestantism of England, Edward died in 1553, and with him any hopes of Protestant domination, at least for the time being.

Queen Mary, Edward's sister, took the throne in 1553, and with her accession Catholicism regained a dominant hold over England. Mary was a devout Catholic and orchestrated the realignment of the English Church with the papacy. Once Roman Catholicism had been restored in England, Mary facę the question of how to deal with English Protestantism. Heresy Laws were reenacted and English Protestants chose either to recant, go into exile or face the Marian persecution. Lines were officially drawn: Catholics were protectors of the sacred and "true" religion while Protestants claimed the mantle of martyrdom, dying for their pure and "true" beliefs. It was a battle of equal and opposite truths--a battle that would not die with Mary and the dominance of English Catholicism, but would be continued by writers such as Thomas Stapleton. After Mary's death in 1558 , her sister Elizabeth took the throne and Protestantism was accepted as England's national religion.

The accession of Elizabeth also meant that Catholicism and Protestantism reversed the roles that they had had under Mary. The English Church was now a Protestant-dominated institution, and Catholics either recanted, went into exile or practiced their Catholicism secretly. Religious life in England became relatively stable from 1558 to 1580 . The year 1580 marked foreign Catholicism's attempt at a 
reemergence in England, an attempt that would also see the roles of persecutor and persecuted that had existed under Mary's reign again reversed. A Protestant Crown would be the persecutor and Catholics the persecuted. The arrival of Jesuits and Catholic ministers from the European continent coupled with a national anxiety and fear of continental Catholicism and the papacy, directed the English government to begin persecutions against Catholics in 1581. The Crown persecuted the Jesuits and Catholic priests as traitors, men determined to overthrow the peace of England and claim England for a foreign power. Again, martyrologies were written to counter the royal proclamations that defined these Catholics as traitors. The Catholic martyrologies were followed by anti-martyrologies that defended the persecutions and directly refuted the martyrological accounts. The pro-persecution material that defended the persecution, most notably the anti-martyrologies, were defending their version of the "truth" to the public. Undoubtedly, the persecutions of Mary and Elizabeth became defined by this battle for the "truth." Although the roles reversed with the accession of a new monarch, both Catholics and Protestants used anti-martyrology and martyrology as a tool, a necessity to purify their cause and to represent their role in the persecutions as the side of divine and absolute "truth."

The Marian and Elizabethan persecutions in sixteenth-century England were driven by similar aims: to stomp out nonconformity against the policies levied by the Church and the Crown. Their goals remained similar, despite the fact that Mary's

\footnotetext{
${ }^{5}$ The background historical information of the English reformation can be attributed to a collection of historical works. The reign of Henry VIII, Edward VI, Queen Mary and Elizabeth is covered by Susan Brigden in New Worlds, Lost Worlds: The Rule of the Tudors 1485-1603 (New York, Viking Press, 2000). Diarmaid MacCulloch describes in great detail the process of Protestantization under the brief reign of Edward. MacCulloch, The Boy King: Edward VI and the Protestant Reformation (New York: Palgrave, 1999). W. K. Jordan's The Development of Religious Toleration in England...to the Death of Queen Elizabeth and Wallace T. MacCaffery's Queen Elizabeth and the Making of Policy, describes the religious settlement and the gradual development of a fear of international Catholicism.
} 
persecutions were focused on Protestant heretics and Elizabeth's on Catholic traitors. The results of the persecutions were the same for both reigns and presented the queens with similar challenges to their authority. The use of persecution as a state-sponsored defense against political and religion criminals created an opportunity for the application of one of the most powerful concepts of the Christian religion: martyrdom.

Reformation-era historian Brad Gregory refers to the reformation as a "renaissance of martyrdom." Martyrdom was a principle component of the suffering of early Christians and one easily applied and imitated by the Protestants and Catholics of the reformation. It was a willful death for a belief or faith. Reformation-era martyrs believed their trials and tribulations paralleled the deaths of early Christians, who had died in order to preserve their faith for future generations. Persecution by the Crown granted men and women a situation reminiscent of the early Christians' suffering and proved that the deaths achieved by the early Church martyrs was possible. This idealized death created a domino effect for those being persecuted. Co-religious and sympathizers either followed the examples of their present martyrs or glorified their deaths with martyrologies. Martyrdom meant that men and women labeled as criminals by the Crown sought death rather than assimilation, but more importantly, that these men and women created a legacy for non-conformity with their death. They would continue to defy the Crown from their graves as martyrologies were written inspiring other people to do the same. The reigns of Mary and Elizabeth witnessed the use of martyrdom to counter persecution, but also witnessed the new type of martyrdom that the reformation created.

\footnotetext{
${ }^{6}$ Brad S. Gregory, Salvation at Stake: Christian Martyrdom in Early Modern Europe (Cambridge: Harvard University Press, 1999), 124.
} 
Instead of the one and only Christian Church persecuting and executing a pagan sect or newly created and fundamentally different Christian heresy, the persecutions of Mary and Elizabeth pitted Christian against Christian, Catholic against Protestant. Monarchical succession carried with it the succession of a monarch's religious convictions and from Henry VIII to Elizabeth, at various times both Catholics and Protestants had enjoyed a dominant and presumed permanent grasp upon English society. Protestants and Catholics, alike, considered themselves to be the "true" Church and the Church of the original martyrs. The result of this unstable religious climate was that one sect attempted to dominate the other with persecutions, and Christians would become the executioners and the executed. Both sides were acting to maintain the sanctity of what they considered to be the one and only Church. Both the persecutors and the persecuted believed their actions to be ordained by God, and in the service of God's will. Those being persecuted viewed and memorialized their dead as martyrs, while the persecutors viewed and glorified their own actions as a defense of the peace and sanctity of England. What emerged was a constant point counter-point battle, the cycle of martyrologies employed to counter the definitions of the persecutions and anti-martyrologies used to defend against martyrdom was present throughout the persecutions of Mary and Elizabeth. Anti-martyrologies and martyrologies persistently tried to attach a label or role upon the other, both denying the validity of the others' actions.

What resulted from these persecutions, Mary's against English Protestants and Elizabeth's against English Catholics, was that the persecuted transformed, glorified and constructed their dead as martyrs. This veneration of a persecuted group, invariably opposed to royal policy and royal decrees, resulted in the need for an equal and opposite 
refutation of the persecuted as "false" martyrs. As men and women were revered in England for their nonconformity and recognized as martyrs, the Crown needed writers not only to defend the persecutions but, more importantly for the future acceptance of continued persecutions, to emphasize to England that the persecutions were just and the executed were not martyrs but heretics or traitors. In essence, anti-martyrologies were a response to martyrologies. Anti-martyrologies would refute and repudiate any attempts at martyr-making. This battle between anti-martyrologies and martyrologies was an integral part of the Marian and Elizabethan persecutions.

What developed during the Marian persecutions from 1553-1558 and Elizabethan persecutions from 1580-1595 was the inability of either group, Catholics or Protestants, to accept the roles attached to them by the Crown and defended by Catholic and Protestant writers and anti-martyrologies. Pro-persecution writings were distributed explaining the persecutions and outlining the crimes of the persecuted. Martyrologies followed that countered the label and crimes attached to their dead. These were followed by anti-martyrologies that restated the crimes of the persecution, demonized the executed, the martyrologists and all those who supported and defended the persecuted. Antimartyrologies and martyrologies became fundamental mechanisms employed by those persecuting and those being persecuted. Martyrologies denied the criminal labels applied by the Crown for the purpose of persecution, and anti-martyrologies countered the label of unjust, unwarranted and merciless persecutor placed on the Crown by martyrological accounts. In this sense, anti-martyrologies were written to realign the public's perception of the persecutions, one possibly altered by the martyrologies, by defining persecution as the Crown's only viable response to heresy and treason. 
Anti-martyrology became a necessity, a tool to strip the opposing side of the purity of their proposed intentions and nonconformity toward and against the realm. It became the medium through which individuals sympathetic to the anti-martyrologists' cause could be reassured, rededicated, and refitted with the protective resolve to weather the storm of heresy and treason. The martyrologies that resulted or sometimes preceded the anti-martyrologies were written to do just the opposite. The martyrologies written after Mary's reign and during Elizabeth's demonstrated that these men and women were not dying in vain or shame, as explained by the anti-martyrologies, but with a purpose and in glory.

The importance of examining and comparing the cycle of persecution and the anti-martyrologies and the martyrologies of Marian and Elizabethan England is to demonstrate the effects of persecution and the frailty it could create within a nation. Despite the Catholicization of England and a Catholic majority, Protestantism remained a constant presence and hindrance to Mary. Despite the Protestant dominance in Elizabethan England and the Catholic minority, Catholicism did not become extinct or slip into obscurity but instead was judged to be an internal threat to the Crown. Both queens deemed persecution to be the only plausible method for controlling these threats; as a result, both the Protestants and Catholics who were persecuted maintained and often furthered their position with their martyrologies that glorified the dead.

The Marian and Elizabethan persecutions proved that there was a catch-22 of persecuting: choose to kill to ensure the peace and royal authority but in the process disenfranchise many, further the opposition and generate sympathy for the persecuted. The truth of the matter, one not acknowledged by the Marian and Elizabethan writers and 
anti-martyrologists but one that justified the need for their work, was that persecutions did not eliminate nonconformists. If the death of English subjects had been the only method needed to remove nonconformity from the landscape of England, then antimartyrologists would have been irrelevant. Anti-martyrologists would have had no one to convince and to defend the persecutions to. However, anti-martyrologists were needed. Protestantism and Catholicism, or more importantly, the threat of nonconformity did not die with the death of its followers. Anti-martyrologies attempted to reverse a person's sympathy, remorse or compassion for persecutions by preventing martyr making and making the persecutions safe and free from any glorifications of the executed. However, the nature of persecution, especially Christian against Christian, proved that martyrdom would remain a variable in the equation of persecuting and neither Protestants or Catholics were willing to accept the roles placed upon them.

These divergent claims, contradictory accounts and the refusal of the persecuted group to accepts its role were the challenges anti-martyrologists faced during the reigns of Mary and Elizabeth. When comparing the queens and the anti-martyrologists of each reign, there are many differences but also many striking similarities. The most striking difference is the lack of anti-martyrological works during the reign of Mary, even though her persecutions created more martyrs than Elizabeth's. Aside from Miles Huggarde and John Gwynethe, no works were produced that specifically refuted martyrdom and attempted to defend the persecutions from martyrdom. Mary's Catholicization of England from 1553-1558 meant that all Protestants who remained did not recant and chose to practice their Protestantism publicly were arrested, tried and executed as heretics. The nature of Mary's persecutions was theological and driven to expel the 
Protestant heresy from England. Marian writers, who explained the persecutions to the English public, applied theological evidence to defend the persecutions and devalue the Protestant martyrs and martyrologies. Elizabeth and her persecutions did not have as firm a footing or an absolute, undoubted, and unquestioned principle as a foundation. The purpose of the Marian persecutions were obvious in both the martyrologies of the Marian writers who defended and vilified the Protestants and the anti-martyrologies that countered martyrdom. Religion was the purpose; Marian writers and anti-martyrologists claiming that the Crown executed heretics and Protestants claiming that the Protestant martyrs were executed by a corrupt anti-religious Marian Catholicism. However, the Elizabethan persecutions claimed to be purely political despite only executing Catholics.

As Elizabeth ascended the throne and enacted a religious peace in 1559 , religion was to be removed, at least publicly, from the internal conflict of England. As an international Catholic threat developed in the 1570 s and focused on a Protestantdominated England, anxiety and fear of foreign Catholicism enveloped Elizabeth and her administration. In order to ensure a lasting peace and stability within England, Elizabeth acted upon this perceived Catholic threat and turned upon Jesuits, Catholic priests and English Catholics during the 1580s. These Catholics were arrested, tried and executed as traitors, not as heretics. Elizabeth was attempting to completely remove religion from the persecution equation in the hopes of maintaining English stability and preventing any attempts at martyr making by the English Catholics. However, Elizabeth's effort at removing the element of martyrdom from the persecutions of the Jesuits and priests failed. Catholic martyrologies were written to refute the label of traitor applied to the Catholics by the Crown, present the true purpose of the persecutions as religious and 
construct their dead brethren as martyrs. The aspect of written and widely distributed martyrologies was something that the Marian persecutions did not face.

The Elizabethan anti-martyrologies that followed the Catholic martyrologies were primarily a state-sponsored program written to defend the actions of the state and the purpose of its persecutions. The Crown issued royal proclamations revealing the internal danger Catholics presented to England and defending persecution as the only answer to maintain peace and stability. For example, William Cecil, an Elizabethan administrator, wrote defending the Crown's actions and emphasizing that the Catholics were being executed as traitors not heretics. ${ }^{7}$ But the persecutions would also be defended by Elizabethan Protestant writers, who presented evidence intended to further incriminate the English Catholics and bolster the Crown's charge of treason. This was the weight of the Crown's and the anti-martyrologists' arguments against Catholic martyrologies: the Catholics were executed for treason against England and traitors could not be constructed or revered as martyrs. Other anti-martyrologies appeared during this period following the release of the Catholic martyrologies, further branding the label of traitor upon the executed Catholics. In writing the martyrologies and anti-martyrologies, both the Crown and the Catholics were attempting to apply and reapply, refute and dispel the labels and perceptions forced upon them by the other.

While the differences between Marian and Elizabethan anti-martyrologists stemmed from the nature of their persecutions and the presence of written martyrologies, their similarities were based on how the process of persecuting began and was executed in England and the methods supporting writers, the Crown and most importantly anti-

\footnotetext{
${ }^{7}$ William Burghley Cecil, The Execution of Justice in England for Maintenance of Public and Christian Peace, Against Certain Stirrers of Sedition, and Adherents, to the Traitors and Enemies of the Realm (London: NP, 1583).
} 
martyrologies applied to define, defend and refute martyrdom. With pen, pamphlets, letters and royal proclamations, the writers who defended the persecutions and the antimartyrologies of Marian and Elizabethan England intended to stem the tide of what they viewed as a dangerous heresy or treason, to counter the evangelical opportunities afforded those that faced public execution and to appeal to the broad range of Englishmen and women to accept the decrees, prohibitions, and persecutions of the Crown. Both Marian and Elizabethan writers introduced the persecutions, defined their presence to England, outlined who they were directed toward and outlined the crimes and danger of the persecuted. The writings printed and distributed throughout the persecutions were peacekeeping tools, or at least an attempt, aimed at those completely opposed to persecution, weary of the Crown's persecutions, or those sympathetic to the persecuted.

Another similarity and aspect of the writings that outlined and defended the persecutions was the inability of those doing the persecuting to understand how English subjects could choose heresy, treason or death over loyalty to their Crown. Those who chose death were choosing it over loyalty to the Queen and conformity to her policies. Disloyalty to the Queen and her policies was something inexplicable to those doing the persecuting and especially to the anti-martyrologist publicly defending conformity. Whether the question was loyalty to the Queen's religion, or simply loyalty to the Queen and the peace of the realm, those that were the victims of the persecutions were guilty of nonconformity, a capital offense in Marian and Elizabethan England.

Marian and Elizabethan persecutions also shared an emphasis on the defense of the purity, the purpose, and the nature of their persecutions. To Marian writers, especially John Proctor, who wrote against Wyatt's rebellion in 1554, any nonconformity 
was not only traitorous to the Queen, but more importantly, driven by heretical motivation. ${ }^{8}$ In Marian England, religious convictions could not be separated from political motivation. Heresy was the motivation of nonconformity, and in defying the Queen's policies, Protestants were defying the true Church and God. Any objection or attempt at glorification was simply a ruse by the Protestants of Marian England. Protestants intended to conceal their heresy and destabilize England with manipulation. As defined by the anti-martyrologies, those who died in the Marian persecutions could only be classified by one term: heretic.

The Elizabethan persecutions witnessed the Crown and anti-martyrologists defend the persecutions in the same way. The Crown's proclamations and defenses took on an anti-martyrological tone and presented the intentions of the Jesuits and Catholics in England as purely traitorous. Their presence was identified simply to conspire against the Queen, provoke her subjects, and worst of all, to take her life. By expanding or plainly accepting as a reality the idea of a monolithic Catholic threat to England organized by the newly arrived Jesuits and Catholic priests, the Crown and its supporters attempted to completely remove religion from the Elizabethan persecutions. English Catholics who had lived persecution-free under Elizabeth's reign were accused of willfully accepting foreign Catholics and international Catholic ideas into England. The Crown considered this as treason, the Jesuits and priests as traitors, and warned English subjects of the danger these Catholics presented to England.

The Crown defended its actions vehemently against Catholic martyrologies. Documents were printed alongside royal proclamations and anti-martyrologies that explained to English people that these persecutions were not directed against Catholicism

\footnotetext{
${ }^{8}$ John Proctor, The History of Wyatt's Rebellion (London: R. Cally, 1554).
} 
alone, but against the traitorous intentions the Jesuits, Catholic priests and sympathetic English Catholics harbored against England. Treason took the place of religion and any nonconformity to Elizabethan policies, or in the case of the English Catholics, simply the threat of nonconformity was defined as treason. Those who died during the Elizabethan persecutions were to be defined by only one term: traitors. It was the role of propersecution writers and anti-martyrologists, under the reign of both queens, not only to perpetuate the label of heretic or traitor but to provide the evidence for this definition and to ensure that the English subjects supported and accepted the persecutions.

Anti-martyrologies were attacked and reversed with martyrological accounts or vice versa. What was at stake? The history of these persecutions. What would the perception be? Would Mary's monarchical authority prove superior to a minority group whose only weapon was martyrdom? Would the Protestants of Mary's reign be remembered as heretics or revered as martyrs? Elizabeth's accession proved that they would be honored as martyrs. Was the religious peace Elizabeth enacted a mainstay of her entire reign, despite her persecutions of the Catholics? Would the Catholics persecuted under Elizabeth be perceived as traitors or revered as martyrs for their religion? The anti-martyrologies and martyrologies of Marian and Elizabethan England proposed to answer these questions, not only for their fellow Englishmen but also for the future subjects of England. The anti-martyrologies and martyrologies took up the mantle of each side, defended their actions, and illustrated the purity of their motives in order to establish their legacy. Both anti-martyrologist and martytrologist were writing on behalf of the "righteous" side of these persecutions, a side free from error or wrongdoing. They 
spelled out to their readers their versions of the absolute truth, and attempted to instill their defenses, or refutations, as the only absolute history of these events.

The following discussion will demonstrate the methods used by the Marian and Elizabethan persecutions to ensure national stability, maintain public support, and most importantly to refute martyrdom. The Marian and Elizabethan persecutions, despite their differences, followed the same blueprint to define the persecutions, describe the persecutions' necessity, describe the danger posed by those who were persecuted and, as martyrdom presented itself, counter martyrdom. Documents are presented within this discussion that predate the persecutions, but are integral components of the Marian and Elizabethan persecutions and the anti-martyrologies that follow. The fragility of persecuting, especially against another Christian group, necessitated that these works define, defend and counter the inevitable application of the concept of martyrdom by the persecuted. What was at stake was the history and truth of these events, which would be decided by which version of the events one accepted: the anti-martyrological or the martyrological. 


\section{HISTORIOGRAPHY}

Discussions and comparisons of the Marian and Elizabethan persecutions, with the main focus on the anti-martyrologies and martyrologies, are mostly absent from historical works. English historians and reformation historians have accurately described the presence of anti-martyrologies in the Marian and Elizabethan persecutions and their role of providing defense for the persecutions of Marian and Elizabethan England, but most focus primarily on one anti-martyrology or focus only on the death of the martyrs rather than the methods employed by Mary and Elizabeth and sympathetic writers to defend the persecutions. This fails to provide an obvious comparison between the persecutions and their most important instrument of defense: the anti-martyrologies. Although the two queens were persecuting for different purposes, the persecutions relied on many of the same methods to defend the persecutions and refute the attempts of those being persecuted at martyr making in order to control public opinion. Historians have not fully elaborated upon this connection because their primary focus has not been on how the Crown protected its persecutions from sympathy and eventually martyrdom, but rather on the facts of the persecutions themselves.

What Marian and Elizabethan historians have presented is the difficulty of persecution in England and the polarity it created. Although anti-martyrologies and martyrologies are only lightly discussed in connection with the polarized atmosphere of England, most English reformation historians have accurately described the atmosphere 
the persecutions created. Elizabethan historian Anne Dillon best describes this polarized atmosphere created by persecutions, writing, "one man's martyr must be another man's heretic." 9 The basis of this simple formula is what generated the writings and controversy between anti-martyrologists and martyrologists during the reign of Mary and Elizabeth. It also provides historians a glimpse at what was at stake in reformation England. Both Protestants and Catholics could not claim the glory of fighting for the "true" side and slanted accounts would be written to reinforce fellow believers, sympathizers, or opposition to the "truth" behind one's cause.

Brad Gregory presents this conflict between anti-martyrologies and martryologies in Salvation at Stake, a comprehensive history of martyrdom in Reformation Europe. Gregory's book is primarily concerned with the "renaissance of martyrdom" created by the European reformation, the make-up of a martyr, and the importance of martyrdom for Protestants, Catholics, and Anabaptists. But in discussing martyrdom for each, Gregory describes anti-martyrology and says what was "at stake was Christian truth itself." 10 Since both Protestants and Catholics claimed to be the descendants of the "true religion" and the only religion, the anti-martyrologies and martyrologies of Marian and Elizabethan England were competing for the truth. Gregory demonstrates that martyrdom and Christian truth had once been simple; Christians died at the hands of others and were glorified as martyrs. As Christians took on the role of the persecutors and the persecuted, Christian martyrdom and truth lost its simplicity. As will be seen with the writings outlining and defending the persecutions and the anti-martyrologies of the Marian and Elizabethan, their presence further complicated the process of martyrdom.

\footnotetext{
${ }^{9}$ Anne Dillon, The Construction of Martyrdom in the English Catholic Community, 1535-1603 (Burlington: Ashgate Publishing, 2002), 3.

${ }^{10}$ Gregory, Salvation at Stake, 301.
} 
What was at stake within Marian and Elizabethan England was the history of this "truth" and how the men and women who died during the Marian and Elizabethan persecutions would be remembered. Who would history remember as the "true" martyrs or the "false" martyrs?

This battle over who were the true and who were the false martyrs of Reformation England is apparent in historians' accounts of the subject. The Reverend Ronald Knox wrote a Theology of Martyrdom in 1928 that was compiled in a collection of papers discussing martyrdom for Cambridge University. Although Knox's comments are heavily biased with his Catholic convictions, the importance of including Knox's comments on martyrdom is the timelessness of the argument. Nearly four-hundred years after the end of the Marian persecution, Knox explains what a true martyr is, saying it is "one who dies not merely to hear testimony, but testimony to the truth...martyrdom, as a theological term, means dying to bear witness to the true religion... which is, as we happen to know, the Catholic religion." arguing in 1928 that the Protestants and their martryologies continually misreported the history of the persecutions. Although Knox should not be considered an antimartyrologist, his statement demonstrates the intensity of the controversy detailed within the anti-martyrologies and the martyrological accounts.

One common denominator agreed upon by reformation historians and English historians is that anti-martyrologies were necessitated by the power of martyrdom and the fear it created within the Crown. Martyrdom carried such an immense weight and propaganda effect that Mary and Elizabeth, despite the support of Church, state, the

\footnotetext{
${ }^{11}$ Reverend Thomas Knox, "Theology of Martyrdom," The English Martyrs: Papers From the Summer School of Catholic Studies Held at Cambridge, July 28-August 6, 1928, ed. Rev Dom Bade (Cambridge: Harder Book Co, 1928), 5-6.
} 
majority of England, and the fact that their persecutions were directed at an ostracized minority group, both relied on sympathetic writers and anti-martyrological accounts to provide validation and defense of their persecutions. What was it that was so threatening about a small group of people glorifying their dead? What was so intimidating in martyrdom that it necessitated responses from the dominant majority to refute and remove attempts at martyr making from the persecutions?

Gregory calls martyrdom, during its renaissance, "more powerful than a thousand sermons." ${ }^{2}$ Knox called martyrdom a "quasi-sacrament," comparing a martyr's death to a soul- altering experience. Knox viewed this as a sort of "sacramental absolution"13 that carried the ability to purify the soul. Such men and women died for an ideal passed down from the ancient Church and described in the Old and New Testaments. Knox described the relationship between the purity of a martyr and the brutality of those who persecuted. He wrote that martyrs were executed by those "who hated the Christian religion, for the sake of the Christian religion." ${ }^{\prime 4}$ Persecutions pitted good versus evil, and these labels were applied and debated by martyrologies and anti-martyrologies. "True" martyrs versus "false" martyrs. English reformation historian David Bagchi says that it was not the intensity of a martyr's suffering that glorified and drove men to martyrdom but the "truth of their cause." 15 Historians have accurately constructed the immensity carried by martyrdom that anti-martyrologists were trying to prevent. Miri Rubin says these men

\footnotetext{
${ }^{12}$ Gregory, Salvation at Stake, 135.

${ }^{13}$ Rev. Knox, Theology of Martyrdom, 7.

${ }^{14}$ Ibid, 10

${ }^{15}$ David Bagchi, "Luther and the Problem of Martyrdom" Martyrs and Martyrologies: Papers Read at the 1992 Summer Meeting and the 1993 Meeting of the Ecclesiastical History Society, ed. Diana Wood (Oxford: Blackwell Publishing, 1993), 214-15.
} 
and women would become "gods...mythmakers, and lend legitimation to who ever may claim them." 16

The Marian historians who discuss the reign of Mary, her persecutions and the martyrdom of the Protestants recognize the presence of anti-martyrologies but focus their main arguments on other aspects of the persecutions. They often cite the antimartyrologist Miles Huggarde, and while his work is the most important piece of Marian anti-martyrology, it does not stand alone in displaying how the government prepared the realm for persecutions, the fragility the persecutions created in England and ultimately, how anti-martyrological work proved the best defense for martyrdom. Sarah Covington, in her discussion of martyrdom in Marian England describes Miles Huggarde as a Catholic polemicist whose work attacked the bravery and steadfastness of Protestant martyrs promoted by English Protestants. Her only comment on the methods applied is that Huggarde attacked the Protestant martyrs for their "cowardly use of gunpowder" 17 to swiftly end their torture. While this does hit upon one way in which Marian antimartyrologists defined Protestants and refuted them as martyrs, it fails to focus on other anti-martyrologists and other methods applied by Catholics to align public opinion against the Protestant. What is missing is the intensity and frequency of pro-Catholic and pro-persecution writers and the methods they applied alongside anti-martyrologies to demonize and refute Protestant martyrdom claims.

Marian historian Thomas Betteridge, in Tudor Histories of the English Reformation, details some Marian writers' attempts at explaining Protestantism to

\footnotetext{
${ }^{16}$ David Rubin, "Choosing Death? Experiences of Martyrdom in Late Medieval Europe", Martyrs and Martyrologies: Papers Read at the 1992 Summer Meeting and the 1993 Meeting of the Ecclesiastical History Society, ed. Diana Wood (Oxford: Blackwell Publishing, 1993), 153.

${ }^{17}$ Sarah Covington, The Trail of Martyrdom: Persecution and Resistance in Sixteenth Century England ( Notre Dame: University of Notre Dame Press, 2003), 196.
} 
Catholic England. Betteridge says they represented Protestantism as a producer of disorder, corruption, social upheaval, and an undermining of royal power. ${ }^{18}$ Betteridge argues that Marian writers believed that "Protestants were not people who held a coherent set of beliefs and doctrines, they were simply debased Catholics, heretics, who twisted words and distorted the truth."19 Betteridge also believes that Marian writers vilified Protestantism by privatizing it and its emergence in England, blaming Henry VIII and his carnal desires for Ann Boleyn. He asserts that Marian writers transformed all Protestants into "miniature Henry VIII's, and only became heretics in order to gain free range for their carnal desires."20 Betteridge accurately describes many of the definitions applied by the Marian writers and anti-martyrologies against Protestant martyrs, methods that would be destroyed by the martyrology of John Foxe in 1563.

The primary martyrological account written to refute these anti-martyrologies during the reign of Mary was Foxe's Acts and Monuments. Foxe's Acts and Monuments is a large collection of martyrologies consisting of evidence to support a majority of arguments concerning the persecutions of Mary. Literary scholar John Knott agrees that "anyone writing on a work as vast and inclusive as the Acts and Monuments must make choices of emphasis." ${ }^{21}$ Since the emphasis of this paper is the effort and ability of martyrologies to rewrite or dismiss the history perpetuated by anti-martyrologies it will focus on Foxe's martyrology becoming history. Historian William Haller says Foxe's work "framed the stories in an account of ecclesiastical history which purported to show

\footnotetext{
${ }^{18}$ Thomas Betteridge, Tudor Histories of the English Reformation, 1530-83 (Ashgate: Aldorshat, 1999), 122.

${ }^{19}$ Ibid, 125.

${ }^{20}$ Ibid, 123.

${ }^{21}$ John Knott, Discourse of Martyrdom in English Literature, 1563-1694 (Cambridge: Cambridge University Press, 1993),13.
} 
that this faith was the same for which the martyrs of the primitive Church died.",22 History was rewritten with Foxe's martyrology, and it was a history that connected the Protestantism of Marian England to the history of the ancient martyrs. Haller explains that this aspect of Foxe's work inspired an English collectivism and was a reason for the religious peace. He says Elizabeth "exploited the gifts and personality and the arts of showmanship at her command to counteract the disruptive effects of religion among her subjects." $^{23}$ Foxe's martyrology granted Elizabeth a foundation on which to build a Protestant nation. Betteridge describes Foxe as constructing the "Marian martyrs as embodying the past, the present and the future of the Elizabethan regime. He makes them the meaning of Elizabeth's reign." ${ }^{24}$ It is questionable whether Elizabeth applied the Acts and Monuments as a tool to promote religious peace, but ultimately it seems likely that a Protestant peace and unity was bolstered by Foxe's portrayal of the conquering Protestantism as the true religion of England. Catholicism was completely dismissed and permanently assigned the role of persecutor and enemy of Protestantism.

The largest controversy of reformation England, one that obscures the process of the Marian persecutions, was the nature and purpose of the Elizabethan persecutions. As noted earlier, Elizabeth persecuted Jesuits and Catholic priests not for religious reason but to clear the realm of traitors. English Catholic historian Arnold Pritchard recognizes this as an atmosphere for another English anti-martyrological versus martyrological battle, both attempting to create the truth of the matter. It was and is remembered as more controversial than Mary's persecutions based on the fact that it was unclear as to the exact reason why the Catholics were persecuted. Marian Protestants were

\footnotetext{
${ }^{22}$ William Haller, Foxe's Book of Martyrs and the Elect Nation (London: Jonathan Cape, 1963) 224.

${ }^{23} \mathrm{Ibid}, 225$.

${ }^{24}$ Betteridge, Tudor Histories, 162.
} 
undoubtedly tried as heretics, but in Elizabethan England the Crown and the Catholic communities cried conflicting reasons. This is why Arnold Pritchard asserts that the "longest standing debate about the English Catholic mission and the government's reaction to it has been whether the missionaries who were executed died as martyrs or as traitors." 25 There is no simple answer to this debate, and while it began between Elizabethan anti-martyrologies and Catholic martyrologies, it continues in the historical works discussing Elizabethan England.

Gregory describes the Elizabethan persecution and its executions of Catholics as traitors as an ingenious plan by the Crown to persecute without religion and, in the process, to deny the martyrdom that might result and still maintain a persecution based on non-religious motives. ${ }^{26}$ Dillon writes that treason was chosen as the purpose of the persecutions because the "government argued that the papacy was attempting to withdraw the Queen's subjects from their natural and lawful allegiance by usurping her role as Supreme Governor of the English Church and her sovereignty in general."27 Dillon was writing in defense of the Catholics. The argument's flaw is the author's inability to correctly comprehend the truth of an international Catholic threat to England, how threatening the English Catholics were to the safety of England, and how much was this threat embellished by the Crown.

Royal proclamations were issued from the Crown, its ministers spoke out in defense of the persecutions, writers colluded in the defense of the persecutions and antimartyrologies presented evidence that, as Covington says, depicted the Jesuits and

\footnotetext{
${ }^{25}$ Arnold Pritchard, Catholic Loyalism in Elizabethan England (Chapel Hill: University of North Carolina Press, 1979), 23.

${ }^{26}$ Gregory, Salvation at Stake, 328.

${ }^{27}$ Dillon, Construction of Martyrdom, 17.
} 
Catholic missionaries as aligning with "international and papal powers to overthrow the Queen and the Church of which she was supreme head."28 Granted, most of the Elizabethan historians acknowledge the international efforts of Catholicism, including the counter-Reformation, as a threat to Elizabethan England. Unfortunately, what is missing from previous scholarship is the intensity with which Elizabeth and her ministers defended what became a state-sponsored anti-martyrology campaign by promoting the threat of the Jesuits and priests in England. Covington does recognize this aspect of the Elizabethan persecutions, commenting that the "charge of treason was a government designation propounded most loudly by William Cecil." ${ }^{29}$ Covington also acknowledges that other sources existed outside of the papers issued from the state but does not draw upon their extreme relevancy in a discussion of the Elizabethan persecutions. It was not the Crown alone that intensified English anxiety; anti-martyrologists, outside of the Crown, also contributed in enveloping England in a state of paranoia about foreign Catholicism.

Frederic Young, Jr. offers the most insight into the anti-martyrology writings that were distributed in Elizabethan England, specifically focusing on the royal proclamations. Youngs concludes that it was these works, especially the royal proclamations, that defined and publicly convicted the Jesuits of treason, that provoked martyrological responses. Youngs speaks briefly of William Fulke and Anthony Munday, but does not present their works as an integral part of the anti-martyrological process. Instead, Youngs comments that "many works have been printed showing how

\footnotetext{
${ }^{28}$ Covington, Trial of Martyrdom, 163.
}

${ }^{29}$ Ibid, 161. 
the Government's charge of treason had been 'proved' at Champion's trial, while others were issued to demonstrate the cowardly way he allegedly found execution., ${ }^{30}$

This argument based on the intentions of the Jesuits and Catholic priests in England during the 1580 s becomes much clearer, at least to revisionist historians, who focus on Catholic martyrologies written during the Elizabethan persecutions. Arnold Pritchard believes that the English Catholics were in an unwinnable situation and were being persecuted simply for their presence. He believes the priests' only treason against the Crown was their "mere presence in England." 31 Pritchard writes that this "certainly indicates that the government could find nothing more incriminating against them than the exercise of their priesthood." ${ }^{32}$ Gregory agrees, commenting that the evidence against the Catholics in most cases was suspiciously thin and instead of being used to punish treason was used to make traitors. ${ }^{33}$ Historian Michael Questier argues that the documents convicting the Jesuits were so integral to the defense of the persecutions because of their interjection of political purposes. In doing so, Questier also argues that the Catholic martyrologies were de-politicized. ${ }^{34}$ However, it can also be said, and the Catholic martyrologies claimed this, that the persecutions had been de-religionized with the Crown's charge of treason. This is the belief of Elizabethan revisionist historians, that the intentions of the Jesuits were pure and the persecutions of Elizabeth contained a "falseness."

\footnotetext{
${ }^{30}$ Frederic Youngs, Jr., "Definitions of Treason in an Elizabethan Proclamation," The Historical Journal, Vol. 14, No. 4 (December, 1971), 684.

${ }^{31}$ Pritchard, Catholic Loyalism, 9.

${ }^{32}$ Ibid, 9.

${ }^{33}$ Gregory, Salvation at Stake, 275.

${ }^{34}$ Michael Questier, "Practical Antipapistry during the Reign of Elizabeth I," The Journal of British Studies, Vol. 36, No. 4 (October, 1997), 371.
} 
English Catholic historian John Bossy says that the Jesuits' appearance in England was purely innocent. Bossy argues that they were as a "merchant doing business with customers, a commercial traveler for an old established firm offering to the householder, in competition with new vigorous rivals, a commodity for whose consumption there was limited demand." ${ }^{35}$ Similarly, Dillon argues that the Jesuits and priests were present in England purely to "minister to the Catholics and to reconcile the schismatics and the seculars" and were "instructed not to approach the heretics." ${ }^{36}$ Adrian Morey writes that ground rules were given to the Jesuits and priests by their superiors before they departed for England. He asserts that the mission was "intended for Catholics only; they were to avoid mixing in politics and mentioning the subject in writing to their superiors in Rome; and conversation about the Queen was to be avoided at all costs." 37

By defending the English Catholics' intentions as innocent of their charges and loyal to the Queen, English Catholic historians have sided with the Catholic martyrologists that presented their accounts as the absolute truth of the matter. Dillon considers Allen's True Report the most significant of early official printed English Catholic texts. ${ }^{38}$ As Pritchard explains, the Catholic martyrologies displayed the executed Catholics as having "no political purpose, and in almost all cases their claims seem to have been correct." ${ }^{39}$ Morey writes that the priests lacked any political intentions because the Catholic martyrologies stressed loyalty to the Queen and realm.

\footnotetext{
${ }^{35}$ John Bossy, The English Catholic Community: 1570-1850 (London: Darton, Longman and Todd, 1975), 20.

${ }^{36}$ Dillon, Martyrdom English Catholic Comm, 87.

${ }^{37}$ Adrian Morey, The Catholic Subjects of Elizabeth I. (Totowa: Rowan and Littlefield, 1978), 63.

${ }^{38}$ Dillon, English Catholic Comm, 79.

${ }^{39}$ Pritchard, Catholic Loyalism, 9.
} 
What the Elizabethan royal proclamations, the anti-Catholic conspiracy writings, and William Cecil's anti-martyrological writings contribute to the discussion of the Elizabethan Catholic martyrs is similar to the argument made by historian Michael Questier. Questier considered the anti-papistry of Elizabethan England and its climax with the Elizabethan persecutions to be a practical and pragmatic response from Protestant England. Although Questier's main focus is the northern uprising of 1569, his argument is constructed around the Catholic anxiety that permeated England. Gradually, throughout Elizabeth's reign Catholicism had been accepted in England, granted a quiet observance and had generally been removed from continental Catholicism. Christopher Haigh, an Elizabethan revisionist, admits that the English Catholics had forged a separate identity--one that identified the Catholicism imported by Jesuits and the Catholic missionaries to be a "new fangled Catholicism." ${ }^{40}$ What the Jesuits and Catholic priests presented to England and English Catholics was change. Questier is correct in arguing that change was the primary fear of Elizabethan England--fear that Catholics would rebel from the position that they and Protestants had grown comfortable with. Above all, the papacy and the Catholicism brought by the Jesuits and Catholic missionaries "destroyed social cohesiveness, and the foundation of the commonwealth." ${ }^{41}$ In light of the royal proclamations, the numerous anti-martyrological works and the fact that Jesuits and Catholic missionaries were the first and only to be executed, the Crown took this threat seriously and was determined to prevent change within the Elizabethan Catholic community.

\footnotetext{
${ }^{40}$ Christopher Haigh, "The Continuity of Catholicism in the English Reformation" Past and Present, No.93(November, 1981), 38.

${ }^{41}$ Questier, "Practical Antipapistry," 391.
} 
The final question when discussing the role and methods of anti-martyrologies and martyrologies in the persecutions of England is: were persecutions and antimartyrologies the answer to the question of nonconformity? Gregory believes persecution was called for as a display of royal power and necessitated by any rebellion toward royal policies. He writes that the outcome of "many people of a given group being executed for their religious convictions might simply mean that authorities were doing their job well." ${ }^{42}$ Even during Mary's persecutions, when public sentiment turned against the Queen, the persecutions were carried out to solidify and galvanize a secular rulers authority. According to Gregory, the truth behind the Marian and Elizabethan persecutions was that heretics and traitors were enemies of the realm and capital offenders who would be met with capital punishment. While this is ultimately the case, it over simplifies the persecutions as merely executions of criminals, thereby classifying them as lawbreakers executed with the full support of the realm. However, the persecutions were not that simple. It was not merely a case of criminals being arrested, tried and executed. Religion was involved and posed a threat to turn many against the Crown. Mary and Elizabeth faced the possibility of disenfranchising loyal subjects with their executions and they relied on anti-martyrologists to present the countless pieces of evidence that characterized these men and women as criminals but also provided defense for the capital punishment employed as the answer for nonconformity.

Covington believes that persecution was not successful in solidifying royal power but instead proved a method to further polarize England. Martyrologies were written that proved the executed would not be accepted as heretics, traitors or public offenders but glorified as resisters for a "true" cause. Covington says that the Marian and Elizabethan

\footnotetext{
${ }^{42}$ Gregory, Salvation at Stake, 79.
} 
persecutions were not examples of "persecution's effectiveness, or its power, but of its ultimately impotent futility." ${ }^{43}$ Instead, Covington correctly describes the belief that "religious affliction rested on unstable and contingent ground, as persecutions could backfire on the authorities and became a force for creating sympathy if placed, for example, in the hands of a martyr able to exploit his torments for higher spiritual purpose." ${ }^{44}$ Knott comments, in his discussion of Marian martyrdom, that Stephen Gardiner, who presided over the first executions, could have called for an ease in the executions as he realized that the leading Protestants would rather die than recant. Instead, Knott writes that Mary was "determined to proceed, in the face of the growing popular resistance that the executions continue." 45 Why choose to persecute when faced with martyrdom and persecutions that could elicit sympathy for the executed? Because the Crown was the final authority, and anti-martyrology could be counted on to defend the persecutions and refute any attempts at martyrdom.

Historical works focused upon the process of persecuting and the resulting battle between anti-martyrologies and martyrologies in Marian and Elizabethan England are practically nonexistent. What Marian, Elizabethan, and reformation historians do accurately display is the atmosphere that the persecutions created, the splintering of what was considered the truth of the persecutions, and the presence of anti-martyrology in this atmosphere. While these historians correctly depict the atmosphere of England, the success or failure of the persecutions, and the inability of the either side to accept the labels attached to them by the other, there is no in-depth examination of the most important sources of this conflict: the anti-martyrologies.

\footnotetext{
${ }^{43}$ Covington, Trail of Martyrdom, 5.

${ }^{44}$ Ibid, 5.

${ }^{45}$ Knott, Discourse of Martyrdom, 14.
} 
As the following pages will demonstrate, the anti-martyrologies of Mary and Elizabeth reveal the full story. Anti-martyrologies presented the threat of nonconformity, the fear of martyrdom, and the urgent appeal to the English people to support the persecutions. Martyrdom was a result of persecution--a powerful and dangerous result and an idea not easily dispelled. However, anti-martyrologies were written and directed toward members of the group being persecuted, English subjects susceptible to being swept up in the martyrs' evangelism, and subjects who harbored no opinions either way. The hearts and minds of the English subjects were contended for and intended to be won with anti-martyrologies. While some took the form of formal proclamations, others pleaded on a personal level with all of England to stand firm in the face of this nonconformity and place their trust in the Crown. Gregory was correct, what was at stake was the truth. However, the truth would be determined by whose account of the persecutions a person held as true, the anti-martyrologies or the martyrologies.

It was not simply a case of accepting the persecutions as a Protestant or a Catholic and allowing one's perception to fall into the applicable category. The power of believing, following, and maintaining the validity of one's cause or its purpose as the "true" cause was what created the atmosphere in England for contradicting works and what carried this debate to present times. Truth versus truth is not a battle that is easily won or defended. The only way of derailing people's belief in the truth of situations and events was to attack the source or center of these beliefs: martyrdom. Although this was not the opposition's most vulnerable point, an attack on martyrdom and martyr-making was the only viable defense for the Crown's actions. Since belief and evangelism rested on the actions of men, presenting these men as cowards, traitors, devoid of noble traits, 
ignorant, shrewd, and above all dangerous, humanized the martyrs. Anti-martyrologists personalized the truth, just as martyrologies appealed to people on a personal level. Continuance of nonconformity meant only one thing, the subjection of the Crown, all of England and one's family to the whims and danger of those being persecuted. Antimartyrology was the one and only defense Protestants and Catholics had when faced with martyrdom. Therefore, anti-martyrologies must be studied as just as integral part of the martyrdom process as the martyrologies that glorified the dead.

The primary documents presented within this discussion differ when comparing the reigns of Mary and Elizabeth. Marian England did not produce many antimartyrological works and those that specifically refuted Protestant martyrdom did not have to combat written martyrologies spread throughout England, as did the antimartyrologies of Elizabethan England. The Elizabethan persecution's antimartyrological works included many sources written and distributed directly by the Crown and directed toward an England that had access to Catholic martyrologies. Despite these differences, the works discussing, defining, defending the persecutions and refuting martyrdom followed a similar process and employed many of the same methods. The primary sources chosen from the Marian and Elizabethan persecutions delve into the process of persecuting and its relation to the English public. All these documents, antimartyrological or martryological, were written for mass consumption and with the purpose of creating, bolstering and maintaining a perception of the events that the subjects of England were witnessing.

Mary and Elizabeth, because of persecutions and martyrologies, were striding toward a label of persecutor rather than national savior. The sources analyzed in the 
following discussion present the process by which the Crown, sympathetic writers and anti-martyrologists defined the persecutions, described the necessity of the persecutions to the English people, rationalized death and created English solidarity in persecuting and executing fellow English subjects. The chronology of the primary sources of the Marian persecution allowed their readers to slowly follow the course the Crown had decided, the threat that these persecuted men and women presented, and as martyrdom reared its head, the methods by which the persecutions would be defended from martyrdom.

The first step of persecution writers, under the reign of both queens, was to define the persecutions. William Barlow outlined the Protestant heresy in 1553 and in doing so began the incrimination and demonization of English Protestantism. ${ }^{46}$ John Proctor's account of Wyatt's rebellion, a political uprising in Kent, granted the Crown the means to define nonconformity against the Queen's policies. ${ }^{47}$ Wyatt cried political motivation as his concern and instigation of an uprising, but Proctor would present to England that any nonconformity had only one label in England: heretic. Proctor's history laid the framework for the anti-martyrologies that would follow. Proctor depicted the English Protestants as deceptive and manipulative and subjects who would describe rebellion and nonconformity in many different fashions in order to overthrow the Queen. John Ponet's writing is included in order to display this fact. It was an attempt to undo the definition of nonconformity; that all nonconformity was heresy. ${ }^{48}$ Ponet argued that English subjects could rebel for reasons other than religion. Ponet's writings also displayed to the

\footnotetext{
${ }^{46}$ William Barlow, A Dialogue Describing the Original Lutheran Factions, and Many of Their Abuses (NP, 1553).

${ }^{47}$ John Proctor, The History of Wyatt's Rebellion (London: R. Cally, 1554).

${ }^{48}$ John Ponet, A Short Treatise of Politic Power (Winchester: NP, 1556).
} 
Crown, Marian writers and eventually anti-martyrologists that the Protestants intended to draw support for their heretical intentions by manipulating the public.

As for anti-martyrological work in Marian England, work that specifically focused on, mentioned and argued for the presence of "false" martyrs, there was very little distributed. Why? One answer is that Marian England strictly controlled the presses, especially those that printed material opposed to the Crown, and did not face the number of written and distributed martyrologies as did Elizabeth. The lack of documented martyrologies possibly contributed to the lack of anti-martyrologies being written, or perhaps death and execution was the best deterrent for sympathizing with Protestantism. The brutality and length of the persecutions possibly contributed to the lack of anti-martyrologies needed to defend against nonconformity; blood was enough. Whatever the reason, Miles Huggarde and John Gwynethe are prime examples of antimartyrologies and the evidence and arguments used to counter martyrdom. ${ }^{49}$ Huggarde's work is the most comprehensive and most developed in its refutations, but Gwynethe contributed to the defense against martyrdom, relying upon the same methods and attacking the same qualities as Huggarde.

These two anti-martyrologies, analyzed together and with prior defenses of the persecutions, present a clear picture of how persecutions were defended and the best way decided by Marian writers to combat martyrdom. Since Mary's persecutions, as defined by Proctor and furthered by Ponet, were directed against manipulative religious heretics, the persecutions and refutations would need to be defined in religious terms. What Huggarde and Gwynethe present is an explanation for heresy and the presence of "false"

\footnotetext{
${ }^{49}$ John Gwynethe, A Declaration of the State Where in All Heretics Do Lead Their Lives (NP, 1554). Miles Huggarde, Displaying of Protestants (NP, 1556).
} 
martyrs. They defined the meaning of heresy, its justification, its danger, its true purpose, and ultimately its vulnerability. Huggarde and Gwynethe focused on what the Protestants used to define their dead as martyrs. These martyrdom qualities were transformed from commendable act of faith and service to acts of insanity and evil. While the lack of martyrologies and anti-martyrologies during the reign of Mary proves that the Crown dominated public opinion and emotions about persecuting, Proctor's account and the anti-martyrologies that followed proved that there was a legitimate need to define, explain and defend the persecutions to the English public and that there was a belief that martyrdom was combatable. This is what the anti-martyrologies of Marian and Elizabeth prove and what remains unexplored by previous historians.

Foxe's Acts and Monuments is presented to prove how history and antimartyrologies would be rewritten. Foxe's contribution to this discussion of the Marian and Elizabethan persecutions is the way in which martyrologies countered the persecutions, anti-martyrologies and, ultimately, attempted to rewrite history. Foxe's martyrology also provides a comparison for the martyrologies of Elizabethan England and a close analysis of how martyrologists glorified their dead and bolstered their cause. Foxe's martyrology is the most highly regarded work of the English reformation and it is this fact alone that allows one to see the power and importance of martyrological works on the history of a persecution.

Defense of the Elizabethan persecutions followed the same blueprint as the Marian persecutions, except that the Crown and governmental administration took a stronger role. The process of defining the Elizabethan persecutions fell on the hands of the government. The Elizabethan government was attempting to only persecute members 
of a religious group for non-religious reasons. The Crown explained the presence of foreign Catholics to an England comfortable with what had been for twenty years an irrelevant English Catholicism. As we will see, the royal proclamations of 1580 and 1581 defined the Jesuits and Catholic missionaries as enemy subversives, but they also defined the persecutions that would soon follow. In 1580 England was enveloped in a fear of external foreign Catholicism and this was what the Jesuits and Catholic missionaries represented to the Crown. The royal proclamations of 1580 and 1581 described the Jesuits' and Catholics' intentions in England as impure. They were not on an evangelical mission but a mission of espionage and sabotage, and their goal was to overthrow Elizabeth. The persecutions that would follow would be an act of defense against Jesuits and Catholic priests, not for religious reasons but because they threatened the peace of England.

The responses of Catholics denied the charges of disloyalty levied against them and, instead, pledged loyal service to the Queen, as in William Allen's Apologie. ${ }^{50}$ Once persecutions began and continued, the Catholic martyrologists removed their objectivity and pledge of obedience, and began combating the persecutions with martyrdom. The appearance of the Catholic martyrologies, written by William Allen and Thomas Alfield, allowed the Catholics to continue in the defense of the Jesuits and Catholic priests intentions, but now the persecutions would be accepted as ordained by God. Allen's and Alfield's works were standard martyrologies and very similar to Foxe's. They glorified the act of dying well and martyrdom qualities, but their importance was the emphasis on

\footnotetext{
${ }^{50}$ William Allen, An Apology and True Declaration of the Institution and Endeavors of the Two English Colleges. (Mounts Press, 1581).
} 
a martyr's unflinching loyalty to Elizabeth. This was the evidence and qualities latched onto by the Elizabethan Crown and anti-martyrologies as evidence for refutation.

A discussion of the Elizabethan persecutions would not be complete without an understanding of the general atmosphere of England in the 1580s and the fear of Catholicism surrounding it. This is an important subject because this fear of foreign Catholicism, one carried by Jesuits and Catholic priests to England, was the backbone of the Elizabethan persecutions. William Fulke, a Presbyterian, and Anthony Munday both offered examples of the treachery that England was defending itself against. ${ }^{51}$ Fulke and Munday helped legitimize and further stir the fear of foreign Catholicism that dominated England. Munday's works offer insight into how this fear inspired zealotry and paranoia in certain segment of the English population. These documents, whether offered as mere propaganda or factual accounts, resulted in incitement. The Catholics' intentions were artistically painted, the depth of their treason revealed and England either chose to support the Crown's persecutions or find itself subjected to foreign Catholicism.

The proclamation of 1582 and the writings of William Cecil, Elizabeth's chief minister, directly attacked Catholic martyrdom and their "true" purposes in England. Mention was made of the martyrologies or slanderous writings circulating England that had filled the country with lies and deceit. Cecil's writing is a good stopping point for an anti-martyrological discussion of the Elizabethan persecution because it states what was

\footnotetext{
${ }^{51}$ William Fulke, A Brief Confutation of a Popish Discourse: Lately Set Forth and Presumptuously Dedicated to the Queens Most Excellent Majesty. (London: George Byshop, 1581). , A Confutation of a Popish and Scandalous Libel, in Form of an Apology: Given Out Unto the Court and Spread About in Diverse Other Places of the Realm. (London: John Kingston, ND)

Anthony Munday, A Brief Answer Made Unto Two Seditious Pamphlets...Containing a Defense of E. Champion and His Compliances. (London: John Charlewood, 1582). ,The English Roman Life: The Lives of Englishmen at Rome: The Orders of the English Seminaries...the Banishing of the Englishmen Out of Rome. (John Charlewood, 1582).
} 
eventually achieved: that martyrdom would not work in Elizabethan England and would not be a tool to organize sympathy for foreign Catholicism. Cecil's work summarizes the basis of anti-martyrological writings under the reign of both queens--martyrdom will not work.

This approach applied to the primary sources of Marian and Elizabethan England provides an in-depth view into the persecutions, the importance placed on public opinion, the lobbying for unanimous support, and the anti-martyrologies' role in creating and swaying this support. The analyses of the Marian and Elizabethan persecutions, taken together, reveals that similar tactics, methods, and measure were taken to validate the persecutions and to combat the creature those persecutions created: martyrdom. Previous Marian and Elizabethan historians fail to describe the entire picture of persecution and its effect upon England. The anti-martyrologies and martyrologies show that death, while an every day aspect of Tudor England, had to be explained, glorified or defended, supported or rejected, and ultimately validated by the persecuted and the persecutors as a necessity. 


\section{MARIAN PERSECUTIONS}

In October 1553, Queen Mary and Parliament ushered in the initial legislation to reverse the Protestant legislation of Edward VI. England began its path toward a return to Catholicization under Mary. Marian historian Thomas Betteridge refers to Mary's accession to the throne as a "lifting of a veil." accession as a monumental moment that brought light to a dark England. Balladeer Richard Beard described the hopes of English Catholicism and the joyous atmosphere created as Mary took the throne. Beard's ballad recalled a storm of Protestantism that had lingered over England, finally to be removed with the accession of a Catholic Queen. Beard wrote, "That God which might have right/ destroy us everyone/ Hath showed himself most merciful/ to help us along." ${ }^{53}$ God had granted England a Catholic savior in Queen Mary and their suffering and patiently endured torture under Henry VIII and Edward VI had ended. God granted Mary to England as a redeemer. Beard described this overwhelming feeling, saying, "But now has he sent down his grace/ and mercy from above/ and showed us undoubtedly/ a token of his love." ${ }^{54}$ Both Mary and her Catholic subjects considered her accession to the throne as a divine mandate that Catholicism would regain its rightful position in England.

\footnotetext{
${ }^{52}$ Thomas Betteridge, Tudor Histories of the English Reformation: 1530-83 (Ashgate: Aldorshat, 1999), 120.

${ }^{53}$ Richard Beard, A Godly Psalm of Mary Queene (NP, 1553), 1.

${ }^{54}$ Beard, Godly Psalm, 1.
} 
Catholicism had been subjected to Protestant rule since Edward VI took the throne in 1547, casting Catholics into an unwanted and inferior status. Mary's divine mandate was to completely expel the Protestant "heresy" and return England to its Catholic roots. To accomplish this, Mary began purging prominent English Protestants in 1554. Edwardian Protestant councilors and appointees were arrested and all foreign Protestants expelled. ${ }^{55}$ Mary refrained from enacting persecutions against the English Protestants until the English Church had been realigned with the papacy. ${ }^{56}$ In November 1554 , this official reconciliation took place and Mary renounced her title as head of the Church of England. Once papal validation and support were in place, in 1555 Parliament reenacted the Act for Burning of Heretics and heresy became a capital offense. ${ }^{57}$

Defined as heretical criminals, the Protestants of Marian England had been given three options. The first, simplest, and most chosen option was to recant and at least publicly practice Catholicism while maintaining Protestant convictions. Protestants who chose this path were expected to conform and assimilate within a Catholic England. Secondly, Protestants could choose to flee from England in order to avoid persecutions and the compromising of faith. The final option, and the one least chosen but most glorifying was to remain in England, openly practice Protestantism, and face persecution. ${ }^{58}$ This was a choice of non-conformity and denial of monarchial superiority in the matters of religion. By denying monarchial superiority, English Protestants were placing their loyalty with a heretical group labeled as an enemy of England. Men and women who made this decision to remain in England were choosing to die. It was the

\footnotetext{
${ }^{55}$ Jasper Ridley, Bloody Mary's Martyrs: The Story of England Terror (New York: Carroll and Graf Publishers, 2001), 51.

${ }^{56}$ Adrian Morey, The Catholic Subjects of Elizabeth I (Totowa: Rowan and Littlefield, 1978), 14.

${ }^{57}$ Betteridge, Tudor Histories, 127.

${ }^{58}$ Andrew Pettegree, Marian Protestantism (London: Scholar Press, 1996), 87.
} 
duty of the Crown, the originator of the persecutions, to explain to England why men and women would choose nonconformity and death. As the prominent Protestants of Edward's reign were publicly arrested, their trials and convictions shared with the nation, and their executions became more public spectacle than the execution of criminals, the Protestants applied the concept of martyrdom to their hopeless cause.

The prominent Protestants of Edward's reign, those most closely associated by the Crown and the Catholic Church with the past and present Protestant heresy, constituted the bulk of the Marian executions up until $1557 .^{59}$ The influential ministers and appointees of Edward suffered alone and without much public support. Marian historian Jasper Ridley describes these men as believers in the "doctrine of Christian obedience, who had patiently suffered without resistance, alone or with fellow martyrs, all the taunts and humiliations inflicted upon them." ${ }^{60}$ These first victims of the Marian persecutions were the standard bearers and models for the Protestant martyrs. They suffered for what seemed to be a faith on the verge of extinction in England, but their bravery and dedication to death over recantation revived the convictions of many English Protestants. It was the ministers of Edward, the men who inspired English Protestants to choose death over recantation, that Miles Huggarde and John Barlow attacked in their antimartyrological writings.

In 1557 Mary extended the arm of the persecutions to envelop all of England. Included were those Protestants who carried no influence, no prominence, only persecuted because of faith and determination. Ridley refers to this phase of the Marian

\footnotetext{
${ }^{59}$ Ridley, Bloody Mary's Martyrs, 63.

${ }^{60}$ Ibid, 171.
} 
persecutions as the Queen's "grass roots" program. ${ }^{61}$ He describes this as the stage of the persecutions that was determined to "find the most humble and obscure people who had never played a prominent part in religious controversy and whose heretical opinions and very existence, was only known to their neighbors."62 This "grass roots" program opened the door of martyrdom to sections of society previously exempt. Martyrs no longer would only be educated elite, but now included the uneducated, illiterate, and secular men and women of England. The common men and women, influenced by the Protestant administrators who had previously faced death, would choose martyrdom. These Protestants chose to die with the belief that a martyr's death was the only way to obtain penance for their sins. ${ }^{63}$ Although martyrdom was resurrected in England, carrying with it a threat to public opinion of the persecutions and a mass propaganda effect, no antimartyrologies were produced after Huggarde's in 1556. Monarchial domination seems to have been the deciding force in refuting martyrdom.

Covington comments directly upon the inability of Protestantism to incite mass opposition to the persecutions, but is indirectly explaining why Marian anti-martyrologies were lacking after 1556 . She says, "When executions ultimately backfired and the martyrs gained the upper hand, the population was not stirred in its sympathies to the extent that a true threat was presented to the state." of England and the Protestant community relied upon songs, pamphlets, prisoners' correspondence from prison, word of mouth and stories to spread the veneration and

\footnotetext{
${ }^{61}$ Ridley, Bloody Mary's Martyrs, 77.

${ }^{62}$ Ibid, 77.

${ }^{63}$ Ibid, 78 .

${ }^{64}$ Covington, Trail of Martyrdom, 197.
} 
accounts of their martyrs. ${ }^{65}$ The letters and correspondence of the Marian martyrs had to be smuggled to continental presses and then smuggled back in England. ${ }^{66}$ A lack of written and circulated martyrologies contributed to the lack of anti-martyrologies being written; their work was not as necessitated as were the anti-martyrological works of Elizabethan England. Huggarde and Gywnethe were defending the persecutions against the spectacle of execution and an attachment to the prominent Protestants of Edwardian England, whereas the Elizabethan anti-martyrologies were defending against written and distributed anti-government martyrologies. However, despite martyrdom's inability to create a unanimous, or at least a majority opposition to the persecutions, martyrdom did affect small numbers of sympathetic English subjects who witnessed the public executions.

Protestants who had recanted when faced with persecutions reversed their convictions and public sympathies based on the actions of their neighbors, friends and fellow Protestants. Martyrdom had a domino effect by inspiring and creating more martyrs. However, the number of those who submitted to death as martyrs was small when compared to the large number of Protestants who recanted or were exiled. ${ }^{67}$ One of the principles of martyrdom and the power it wields is that it does not necessitate a large number of imitators or followers. The influence and zealotry inspired by a few martyrs provided English Protestantism with a foundation for the glorification of the cause. People longed to view the martyrs' anguish, hear their stories, share in their agonies and follow their footsteps to death and glory.

\footnotetext{
${ }^{65}$ Gregory, Salvation at Stake, 145.

${ }^{66}$ Rubin, "Choosing Death?," 153.

${ }^{67}$ Andrew Pettegree, Marian Protestantism (London: Scholar Press, 1996), 87.
} 
The Marian writings introducing, explaining and defending the persecutions developed from the persecutions' need to be rationalized and, eventually, the inspiration that resulted from martyrdom. These writings and anti-martyrologies that followed vary in their correspondence with the dates of the Marian persecutions. William Barlow wrote in 1553 as Mary took the throne and Protestantism was evolving into a national enemy. John Gwynethe wrote in 1554, at a time when the Edwardian Protestants faced execution and inspired fellow Protestants. Miles Huggarde wrote in 1556, as the persecutions were still focused on the prominent Protestants but gradually moving toward an expansion. Barlow's work aided John Proctor's in 1554 in defining and presenting Protestantism to England as a national enemy. Gwynethe and Huggarde's anti-martyrologies were required to counter-act letters, literature, and the image and inspiration created by oral martyrologies and martyr veneration of the time. During the "grass roots" persecutions from 1557 to 1558 , no works were written that focused on "false" martyrdom. However, the pro-persecution writings that do exist and the anti-martyrological accounts apply specific methods to explain the persecutions, defend the persecutions and refute the martyrdom claims of the executed Protestants. What emerged within England as a result of the Marian persecutions was friction--a friction that the Marian writers attempted to correct and resolve. This friction was based on competing ideologies regarding persecution and nonconformity, "true" and "false" martyrdom, and royal authority.

The Marian persecutions divided England along Catholic and Protestant lines. Catholics provided public support for the Crown's persecutions and Protestants provided support and sympathy for those who chose death. England was segmented into Catholics, Protestants, and those who carried no affiliation or opinion. Catholics and 
Protestants relied on anti-martyrological and martyrological evidence to bolster their opinions, defend their side and to reassure themselves. Those that harbored no opinion and were not moved one way or the other based on beliefs and convictions constituted a segment of society whose support would be solicited by both anti-martyrologies and martryologies. Both sides were attempting to gain through anti-martyrologies and martyrologies an absolute majority. For Catholics this would mean the end of Protestantism in England and for Protestants this meant the recruitment of more Englishmen to the Protestant cause.

Questions were directed from Catholic anti-martyrologists to Protestants and Protestant sympathizers. Catholics questioned the loyalty of their fellow English subjects, their sanity, and intelligence. Ridley proposes that many Catholics questioned, "Why were these people so arrogant and opinionated that they chose to be burned when they could have saved their lives by recanting? Why did they not do as ordinary Englishmen did, and change their religion when they were ordered to do so by the government?"68 English Reformation historian Richard L. Greaves argues that Marian Protestants defended themselves by claiming to be victims of tyrannicide. Greaves believes that Protestants rationalized rebellion and disobedience based on the fact that Mary was a tyrant and that tyrannicide "dissolved the contractual bonds with the people." 99 John Ponet's A Short Treatise of Politike Power specifically addresses this, as Ponet urged all of England to rebel, regardless of religious affiliation, based on Mary's tyranny. However, despite political urgings to all of England or political rationalization of their rebellion, Protestants faced a persecution driven by religion and a label of heretic

\footnotetext{
${ }^{68}$ Ridley, Bloody Mary's Martyrs, 154.

${ }^{69}$ Richard L. Greaves, "Concepts of Political Obedience in Late Tudor England: Conflicting Perspectives" The Journal of British Studies, Vol.22, No. 1, (Autumn, 1982), 25.
} 
applied to them. Anti-martyrologies and martyrologies expanded upon these definitions in order to divide England.

What was at stake was the divided England. Anti-martyrologies and martyrologies were written to change opinion, reinforce it, or defend it from coercion. Since the effect of any good propaganda is its ability to align or solicit support and sympathy, anti-martyrologies and martyrologies were no different. It can be assumed by the tone of anti-martyrological accounts and the power of martyrdom that many Englishmen and women, after witnessing Protestant deaths, were moved toward sympathy with the Protestant cause. As persecution continued and its frequency did not subside with the deaths of many Protestants, public opinion began to turn against the Queen and the English Church's crusade against English Protestantism. ${ }^{70}$

By 1557 , the scale and longevity of the executions had reached a point of brutality for many. ${ }^{71}$ Only sixteen heretics had been burned in thirty-nine years under the reigns of Henry IV, Henry V, and Henry VI. Henry VII burned only twelve heretics in twenty-four years and Henry VIII only executed ninety in thirty seven years. These numbers were minimal when compared to the nearly three hundred Protestants executed in three short years under Queen Mary. ${ }^{72}$ Ridley believes that Mary ostracized and threatened many of her subjects when she executed Thomas Cranmer despite his public recantations. Cramner had been the Archbishop of Canterbury under Edward and represented and executed as an Edwardian and Protestant figurehead to Mary. ${ }^{73}$ Wealthy and prominent families, who had recanted under Mary, feared that they still might face execution.

\footnotetext{
${ }^{70}$ Ridley, Bloody Mary's Martyrs, 140.

${ }^{71}$ Ibid, 139.

${ }^{72}$ Ibid, $139-40$.

${ }^{73}$ Ibid, 128.
} 
Public opinion was also disturbed when Mary married King Philip of Spain. Xenophobic and nationalistic English subjects considered this a threat to their national identity and freedom as was present in Ponet's argument against the Crown. ${ }^{74}$ However, Mary's rule and control of public opinion was efficient, and despite a growing wariness about the persecutions, Protestants and Protestant sympathizers still remained a powerless minority. ${ }^{75}$

As arrests and the initial stages of the persecutions began in 1553-1554, a label, role, and identity had to be applied to English Protestants. These were fellow English men and women, neighbors, prominent members of the community under Edward and possibly friends who found themselves suddenly aligned with a heresy punishable by death. What was needed from the Marian writers was detailed descriptions of heresy, who were heretics, what defined them and an explanation of heresy's place in England. The Crown needed to legitimize the arrests, trials and executions it was authorizing. The Marian writers that defended the persecutions in its early stages presented the danger of heresy to the "true" Church and wrote in defense of God and Catholicism. Since Catholicism had claimed the title of the "true" Church in England, Barlow, Proctor, Gwynethe and Huggarde wrote to remove any legitimacy from Protestantism and discredit Protestantism's history in England. They wrote to defend a "truth" that legitimized a Catholicism that had returned to England. Any subject who denied Catholicism or any part of the faith "denieth therein the truth of all the whole."

In defining the Protestants as heretics, Marian writers were also defining the nature of the persecutions. The Marian persecutions were focused on heresy, Protestant

\footnotetext{
${ }^{74} \mathrm{John}$ Ponet, A Short Treatise, 51.

${ }^{75}$ Covington, Trail of Martyrdom, 163.

${ }^{76}$ Gwynethe, A Declaration of the State, 11.
} 
heresy, and nothing more. This was the official claim, despite the fact that the Queen faced a rebellion in January of 1554 motivated, not by religious principles, but by political purposes. Protestant writings also emerged, such as John Ponet's A Short Treatise of Politike Power, which factored in political grievances as reasons for nonconformity against the Queen. In both cases, Protestants were attempting to draw support and followers from outside Protestantism. Sympathetic Catholics, xenophobic English subjects, or the all-important segment not affiliated with either religious group, were persuaded to rebel, deny royal authority, and if not convert to Protestantism, at least sympathize with the Protestant cause and rebel against the tyranny of the Queen. However, as John Proctor's accounts described, and the Marian writers and antimartyrologies supported, in Marian England there would be no distortion of the persecutions or the identity of those who were persecuted. All nonconformists were heretics, persecuted for spiritual reasons, not for a generated treason. The best evidence of an attempt to mix politics with Protestantism was Wyatt's rebellion. It proved to England that heresy was the only role applicable to nonconformity and the death of a heretic the only end for violation of Mary's laws.

John Proctor wrote his history of Wyatt's rebellion, which broke out in mid January 1554 , shortly after the rebellion had been suppressed. ${ }^{77}$ Proctor was a schoolmaster in Kent and eyewitness to the events of the rebellion and therefore accepted as an expert on the motivation of Wyatt and his fellow conspirators. ${ }^{78}$ Proctor's work is important in its insistence on defining Wyatt as a heretic. Proctor presents Wyatt's

\footnotetext{
${ }^{77}$ William B. Robinson, "The National Significance of Wyatt's Rebellion in Surrey," The Historical Journal Vol.30, No. 4 (December, 1987), 780.

${ }^{78}$ William H. Wiatt, "The Lost History of Wyatt's Rebellion," Renaissance News, Vol. 15, No. 2 (Summer, 1962), 129.
} 
motivations in plain terms, although Wyatt's fellow rebels and sympathizers pleaded differently. Proctor's work supported the official stance that nonconformity in Marian England was heresy and any opposition defined as heretical. Those who opposed the Queen could not claim political disenfranchisement; they were Protestants or Protestant sympathizers set on destroying English Catholicism.

In January 1554, Sir Thomas Wyatt led an uprising against the Queen in Kent. Wyatt was a Protestant nobleman in Kent who attempted to instigate a rebellion, not based on Protestantism or religious devotion, but founded on political purposes. Wyatt urged English subjects to join the rebellion in order to counter the Queen's courtship of Philip of Spain and the threat posed by the foreign domination of England. ${ }^{79}$ Catholics and Protestants both feared the ramifications of this marriage and provided Wyatt a controversial issue through which to incite rebellion. ${ }^{80}$ Wyatt's rebellion failed almost as quickly as it was organized, for a lack of support and efficiency of the Crown in suppressing it. Despite Wyatt's cry of a political conspiracy, the history of his rebellion, written by John Proctor, was fashioned to ensure an accurate definition of nonconformity. Religion and politics could not be separated in Marian England, and Wyatt and his followers would be defined as heretics, not freedom fighters. In defining Wyatt's rebellion as a heretical uprising, the tone of the Marian persecutions was set for England. Religious conviction could not be suppressed for political motivation and there could be no compromise. If a person was sympathetic with nonconformity, whether religiously or politically motivated, they would be ensured the death and legacy of a heretic. Ultimately, this was the case for Thomas Wyatt.

\footnotetext{
${ }^{79}$ Morey, Catholic Subjects of Elizabeth, 18.

${ }^{80}$ Robinson, "National and Local," 777.
} 
Adrian Morey refers to Wyatt's rebellion as the incident that cemented Mary's desire to "stamp out heresy at all cost." ${ }^{81}$ Shortly after Wyatt's rebellion in 1554, the executions of Protestants for heresy would begin. Gwynethe and Huggarde's antimartyrologies that shaped, defined, and promoted the Protestants as heretics would follow. Protestantism was defined as dangerous to the safety of the Crown, the Queen and the salvation of England. Proctor's account of Wyatt's rebellion, written shortly after its suppression in 1554, laid the framework for defining nonconformity in Marian England and insisting that heretic was the only label that applied.

Proctor wrote and published his account of Wyatt's rebellion to accurately reveal to England the true intentions of Wyatt' uprising. In the beginning of the history, Proctor described the character of Sir Thomas Wyatt. Proctor said of the man, Thomas Wyatt, "many good and commendable qualities were abused in the service of cursed heresy." ${ }^{12}$ Proctor described Wyatt as having counterfeit purposes. Wyatt was a man who understood the environment that Mary's accession had created in England. Protestantism or heresy was the focal point of Mary and much of England. According to Proctor, Wyatt fully understood the importance of clarifying the

Pretense of his rebellion, to be the restoring or continuance of a newly forged religion was neither agreeable to the nature of heresy (which always defendeth itself by the name and continuance of other matter more plausible)...He determined no worde of religion, but to make the color of his commotion merely to withstand strangers, and to advance liberty. ${ }^{83}$

Proctor presented Wyatt as a shrewd and manipulative heretic, with premeditative intentions to create a rebellion sparked for political concern. By removing heresy from his rebellious motivations, Proctor might possibly attract support, not just from other

\footnotetext{
${ }^{81}$ Morey, Catholic Subjects of Elizabeth, 18.

${ }^{82}$ Proctor, The History of Wyatt's Rebellion, 1.

${ }^{83}$ John Proctor, Wyatt's Rebellion, 4.
} 
Protestant heretics but Catholics as well. Proctor acknowledges the ingeniousness of Wyatt's plan: stir a rebellion based on a fear of foreigners, possibly recruit xenophobic Catholics by removing religion from the causes and ultimately, depose the Queen and Catholicism once and for all. This is what Catholic England faced from its small Protestant minority.

After explaining Wyatt's plan for England, Proctor continues to highlight Wyatt's evil as he moves the history forward. Wyatt embarked for London with the purpose of seeking like-minded people for his rebellion, while his supporters remained in Kent to organize and stir up the population. ${ }^{84}$ Upon entering London, Wyatt spoke to market crowd, attempting to solicit support for the rebellion. Proctor once again reveals Wyatt's deceitfulness with the English people. Wyatt addressed the crowd and was asked if the purpose of his rebellion was truly to defend liberty or actually to dethrone the Queen. Wyatt made his position clear, explaining that his rebellion had no traitorous intentions and instead, might be viewed as an act to assist the Queen. Wyatt's answer was "we mynde no thing less, than...to touch her grace: but to serve her and honour her according to our duties." 85 Wyatt was then asked if he would restore the "right religion again" and responded, "you may not so much as name religion, for that will withdraw you from us the hearts of many, you must only make your quarrel for overrunning by strangers. ${ }^{186}$ Proctor's readers, already tuned in to the deceit and evil within Wyatt's true motives, were invited to witness Wyatt's character but also the danger of heresy to the realm. Proctor's account of Wyatt and the rebellion proved that heretics were more dangerous than

\footnotetext{
${ }^{84}$ John Proctor, Wyatt's Rebellion, 3.

${ }^{85}$ Ibid, 5.

${ }^{86}$ Ibid, 5.
} 
imagined. They would not stop with purely religious nonconformity but would adopt a new guise and employ any means to overthrow the Catholic religion.

Proctor's history of Wyatt's rebellion was written as the absolute and final truth of the rebellion, the historically accurate account. He applied definitions to the rebels, regardless of their true motivation, and he ensured that Englishmen recognized the danger of heresy and the urgency with which Mary and her loyal subjects must engage in order to prevent further rebellions and nonconformity. Proctor stated that the history of Wyatt's rebellion was written so that "they of that age in whose time such things happened, ought by the oft reading conceive a certain gladness. ${ }^{187}$ Ultimately, this was the purpose of every writing that defended the persecutions and of the anti-matyrological accounts that countered martyrdom. A "gladness" was to be fostered in English subjects for taking part in protecting and supporting the Crown, when so many dangers faced the English realm-a "gladness" that the English people were more willful than the heretical and traitorous manipulation that they faced. Proctor's account and the anti-martyrologies that would follow were to be repeated and to take the form of solace for the actions of the time. The Marian writers who explained Protestantism and the persecutions to England and the antimartyrologies were a conscience cleanser for the persecution of fellow Englishmen. "Oft readings" of Proctor's account and the anti-martyrologies of Marian England were repetitive reinforcement for the Catholics of England, who had, despite the purity of their actions, become the persecutors. These were the authoritative histories of the times, ones that glorified Catholic actions, displayed the deception Englishmen faced from their neighbors, and refuted the cause of the persecuted.

${ }^{87}$ John Proctor, Wyatt's Rebellion, 4. 
Proctor's importance to anti-martyrology, although he had written before the persecutions had begun, was that he helped construct the definition for heretical persecutions. The Crown made it obvious to all that the persecutions were motivated by the Protestant heresy. William Robinson argues that Wyatt's Protestantism was the deciding factor for the lack of support from Catholic opponents of Mary's marriage. ${ }^{88}$ Proctor described English Protestants as deceptive and manipulative subjects, who would conceal their heretical purposes behind political motives. Protestants were willing to claim non-religious reasons in an attempt to draw support and sympathy for their actions with broad-based appeals to fellow Englishmen, not just co-religious. The resolution to this problem, one concluded by Proctor, was to define all nonconformity, despite its arguments or claims, to be heretical, just as the Elizabethan administration would define everything as traitorous. These labels were first applied by men like Proctor, to protect Catholicism from Protestant arguments that attempted to dodge the Marian persecutions. It was the role of anti-martyrologists under the reign of both Queens, not only to perpetuate the label, but to provide evidence to support the label.

Evidence of a Protestant design to manipulate English subjects with intentions other than religious was provided by Protestant writer, John Ponet, in 1556. Ponet's writing proved that Protestants attempted to spread the rationalization that rebellion and nonconformity was possible without religious motivation. Ponet's A Short Treatise of Politic Power grants its readers many insights into Marian England and wrongdoings committed by the Crown, not just against Protestantism, but against the entire realm. However, its also grants insight into the need for the works of the Marian writers to explain the persecutions and at whom and why the persecution were being used. The

${ }^{88}$ Robinson, "National and Local," 786. 
definition of acceptable nonconformity was being blurred by Ponet; for the Marian administration there was no such thing and it was the purpose of the Marian writers and anti-martyrologies to make this point stick with England. Ponet discussed monarchial authority, a monarch's obedience to her subjects, and a subject's obedience to a monarch. Ponet proposed a question to the people of England: Could subjects disobey a monarch's absolute power if a ruler's laws, actions and prohibitions defied the laws of God and the laws of nature? Ponet answered by informing the English people that they should "consider and weigh mens commandments, before they be hasty to do them, to see if they be contrary or repugnant to God's commandments. ${ }^{89}$ Richard Greaves asserts that Ponet argued that it was not disobedience but the role of an obedient subject to rebel against tyrannical rule. ${ }^{90}$ Ponet proposed that a monarch created disobedience when a monarch practiced disobedience to the realm and Mary had done just that.

According to Ponet, aside from returning Catholicism to England, which did defy the commandments of God, Mary's major crime against England was her marriage to Philip of Spain. Ponet urged the English subjects, whether Protestant or Catholic, that it was their right to rebel against a hostile takeover by a foreign power. Ponet wrote that Mary's marriage to Philip created the inevitability that foreigners would "invade England, and shall by shiploads (Englishmen) carried into New Spain... ye shall be tied in chains, forced to row in the galleys." ${ }^{91}$ Mary was handing England over and subjecting her English subjects to slavery and domination at the hands of foreigners. By marrying Philip, Mary had "broken her oath and promise" 192 to protect her subjects. Loyalty was no

\footnotetext{
${ }^{89}$ Ponet, A Short Treatise, 51.

${ }^{90}$ Greaves, "Concepts of Political Obedience," 25.

${ }^{91}$ Ibid, 65

${ }^{92}$ Ibid, 65.
} 
longer mandated. Ponet described a situation for Englishmen to resist based on the fact that God's law had been fractured and England handed over to a foreign power that would not separate Catholic from Protestant.

Ponet's Treatise represented further attempts by Marian Protestants to remove the label of heretic from nonconformity. It proposed a united England, urged toward rebellion against the Queen for the sake of English nationalism not a forceful removal of the Catholic Church. Ponet's Treatise, coupled with Wyatt's rebellion, was taken as evidence by the Crown and anti-martyrologists that the persecutions would not be as simple as labeling heretics, trying heretics, burning heretics, and exterminating heresy. Wyatt and Ponet attempted to blur the definition of heresy, or create a situation for the Crown in which heresy would not apply. Marian writers and anti-martyrologists would take this as a challenge to prove that all nonconformity was heresy and that persecutions were the only way to defend a nation against heresy. Anti-martyrologists would present the Protestants' true intentions and purpose to overthrow the Queen and Catholicism.

Marian writers and anti-martyrologies described a protective relationship between the Church and England. This "true" Church, the Catholic Church, was accountable to its parishioners to expel any attempt of deviation form the Church. Miles Huggarde, the best-known Marian writer and anti-martyrologist, wrote of this fundamental Church role, saying that the "true" Church was "permitted forever, thereby to strengthen the weak...to overthrow all non believer sects heretical. ${ }^{93}$ The weak, to Huggarde, was all of England, an England susceptible to heterodoxy and easily swayed from the "truth." Just as Protestants believed in their divinely inspired mission to resist the Catholicization of England, Catholics carried a divine charge to sanctify, purify and defend God's "true"

${ }^{93}$ Huggarde, Displaying of Protestants, 22-23. 
Church from heretical sects. Any Protestant objection to their role as heretics was viewed as unfounded and irrelevant.

This aspect of Marian writing began what would become the controversy over "true" and "false" martyrdom. In defending the "true" Church, anti-martyrologists were also defending martyrdom. They defended the divine act of martyrdom, exemplified by the early fathers and followers of the Catholic Church. According to these writers, Protestants who were executed and glorified by their co-religious were simply using martyrdom as a means to validate their heretical cause. Huggarde proposed that the Protestants look no further than their name to comprehend their role in Christianity. Huggarde asked, "Why are you called Protestants?" He explained that they deserved the name because they protested the "true faith." 94 The Protestants protested, denied the "truth" and attempted measures such as martyrdom in order to bolster their heresy.

What was needed from the Marian writers and anti-martyrologists was an explanation for the existence of heresy. Why had God returned Catholicism to England only to plague it with Protestant heretics? Marian writers and anti-martyrologists proposed several explanations for the presence of heresy. Marian historian Thomas Betteridge describes the attempts of English Catholic writers to explain the presence of heresy as the "privatization of Protestantism." While he is correct, Marian antimartyrologists provided further evidence for the infestation of Protestantism in England. This privatization, described by Betteridge, was a linking of the present Protestants with

\footnotetext{
${ }_{95}^{94}$ Huggarde, Displaying of Protestant,s 11.

${ }^{95}$ Betteridge believes that Protestantism was "privatized" by directing all blame and its existence upon Henry VIII and his carnal desires for Ann Boleyn. Marian Catholic writers portrayed all Protestants as miniature Henry VIII's. Betteridge argues that this "privatization" allowed Marian writers to explain the disorder, corruption and social upheaval that was present in Marian England. Betteridge, Tudor Histories, 122-23..
} 
the past. Henry VIII had plunged England into disfavor with God by expelling the papacy from England. Edward VI only compounded God's displeasure by accepting Protestantism and allowing it to flourish under his reign. Huggarde described Marian Protestantism as the answer for England's past ills. Huggarde wrote, "It pleased God to plague this our country for the gloom of the people, with the unquiet forms of heresy."196 Huggarde compared the plight of English Catholics over the past twenty years to that of the Israelites. God had directed his contempt and vengeance toward his own people since they had strayed form their religion. ${ }^{97}$

Conceptualizing the Protestant heresy as something directed or necessitated by God allowed the Catholics of England to desensitize themselves from the situation. If heresy and persecution was God's will then the English subjects could throw their full support behind the persecutions and accept them as the only answer to the problem of heresy. Marian writer William Barlow consoled his fellow subjects by referring to the timeless, continual presence of heretics and false prophets in the Old and New Testaments. Barlow wrote, "All other false prophets boasted themselves to be sent of God and come to preach his truth, whom he never did send." 98 Writers such as Barlow and Proctor, who defended the persecutions and were followed by the anti-martyrological defenses of Gwynethe and Huggarde, urged England not to be intimidated or afraid of these "false prophets," but willing to face and conquer the heresy as their Christian forefathers had done. Most importantly to the continuance of the persecutions, Catholics needed to fully support their Queen, the Church and the persecutions. Huggarde explained that God had determined Catholics' roles. They were persecutors of heretics or

\footnotetext{
${ }^{96}$ Betteridge, Tudor Histories, 40.

${ }^{97}$ Ibid, 7.

${ }^{98}$ William Barlowe, A Dialogue, 6.
} 
cleansers of the "true" Church. He reminded Catholics that they "must never cause any true Christian to pour out a fortune of tears to bewayle the calamity thereof." ${ }^{99}$ Death had been ordained and directed toward the Protestant heretics by God, and the Queen and Catholics of England were simply servants of His will. They could not allow emotions or sensitivities to obstruct God's wish or their purpose in the persecutions.

Ordination by God, Catholics as willing servants and the Protestant defilement of the "true" religion and continuance in nonconformity equaled capital punishment for the offenders. Capital punishment became the only answer and the only way to expel heresy. Marian writers and anti-martyrologists enthusiastically defended the death sentence. They argued that if Protestantism was allowed to remain and virtually go unpunished, England would depreciate and topple back into the darkness that was present under Henry VIII and Edward VI. Marian writers urged English Catholics to view this as their window of opportunity: conquer anew or allow England to permanently be conquered. This was exactly what Protestantism was attempting. Huggarde wrote that the English Protestants were guilty of corrupting the "consciousness of the vulgar people, infecting the same with poison of heretical doctrine." ${ }^{100}$ The execution of heretics was a function of the Crown and Church necessary to defend the purity and stability of each.

Since the Queen should punish any offense committed against her subjects or realm, Mary had an equal, or greater, responsibility to punish heresy. Gregory explains that Catholic and Protestants alike "considered persistent Christian heterodoxy the gravest of offenses. Men and women deserved severe punishment if they resisted."101 Huggarde explained that "If emperors do punish theft, murder, rape, abuse... why should they not as

\footnotetext{
${ }^{99}$ Huggarde, Displaying of Protestants, 19.

${ }^{100}$ Ibid, 9.

${ }^{101}$ Gregory, Salvation at Stake, 74.
} 
well punish heresy and sacrilege." ${ }^{102}$ What was more offensive to Catholics: murder, rape, or heresy? Heresy, if allowed to remain and take root, was an offense that threatened not only one life or one soul, but the salvation of an entire realm. The heresy laws reenacted were not brutal or vindictive answers to the problem of heresy, but were necessary to ensure the safety and salvation of England. They were enacted for the protection of England, to correct and prevent a return to the past. John Gwynethe was a musician during Mary's reign and published many of his ballads. He also commented on the Protestant heresy and martyrdom, describing the Protestants as "so injurious and hurtful to the commonwealth that if they should live and continue, it would by them so decay, and be trodden under foot that no man should be able to keep what he hath."103 The execution of Protestants prevented this type of anarchical, apocalyptic society from coming to fruition. The solution, as defended by Marian writers, was death for peace, but the question was, why was the peace of England fragile? What was so threatening about the weak and godless minority described by the Crown and the anti-martyrologists?

The answer was that martyrdom, despite the optimism of the Marian writers and anti-martyrologists and their attempts to justify the executions and the presence of "false" prophets, proved a powerful ally for the English Protestants. Despite a Catholic majority and support from the English people, Mary's Catholic domination, or at least her brutal persecutions, created a fragile state of public opinion and Protestantism was not exterminated. Instead, Protestantism remained a constant hindrance to Mary and often furthered itself in England thanks to the act of martyrdom. Executions created evangelical opportunities for Protestants and accounts were spread orally and in written

\footnotetext{
${ }^{102}$ Huggarde, Displaying the Protestants, 62.

${ }^{103}$ Gwynethe, Declaration of the State, 51-52.
} 
form describing and glorifying the executed Protestants as martyrs. Miles Huggarde was confounded with by power of martyrdom when he wrote, "You shall see more people in Smithfield flocking together on heapes in one day then you shall see at a good sermon or exhortation made by a learned man in a whole week."104 Huggarde commented on the fascination of English subjects with those being put to death and their final messages. Huggarde stated that "if their be any bain sights to be seen, or any foolish matters to be heard, lord how they run and sweat in their business." 105 However, for Huggarde and the Crown, this fascination and reverence was the catch-22 of persecuting a Christian sect. Persecute and kill to ensure the peace but in doing so disenfranchise many and further the movement of the persecuted. Martyrdom was a mighty weapon against persecution and one recognized by the writers and anti-martyrologies that defended the persecutions. Barlow described this desperate situation that persecution created for the Crown. He wrote, "They begin with direct salutations, of glorifying persuasions, under the pretense of godly zeal, often times reporting the word God, the gospel of Christ... whereby they would persuade to rude people, that whatsoever they write or teach." 106 The truth of the matter, one seldom acknowledged by Marian writers and anti-martyrologists, was that English Protestantism was not dying with the death of its followers, but persistently surviving.

Instead of despairing over the complexity that persecution had created in England, Marian writers and their anti-martyrologies rationalized the conflict as a positive element. The complexity of the conflict was proof that Catholics were doing God's work and would inevitably be rewarded. However, by looking at the future conquest and peace,

\footnotetext{
${ }^{104}$ Huggarde, Displaying of Protestants, 80.

${ }^{105}$ Ibid, 80.

${ }^{106}$ Barlow, Dialogue, 6.
} 
anti-martyrologists often overlooked the danger of the minority Protestants and the martyrdom they had created. Huggarde compared the English Protestants to the serpent Hydra in the myth of Hercules, paralleling the many heads of the Hydra to the many opinions of Protestantism. ${ }^{107}$ Instead, a more accurate comparison between the mythical monster and Protestantism would have been that despite the severing of the Hydra's heads, many would grow back in its place. What the persecutions had proved in 1556, as Huggarde wrote in The Displaying of Protestants, was that simply severing the heads, or executing a Protestant was not enough. The emotional attachment to martyrdom created more Protestant sympathizers where only one had been killed. English historian Mark Byford comments on this power of martyrdom in his discussion of the county of Colchester under the reign of Mary. Byford says of the persecutions in Colchester, "The more diseased limbs the commissioners tried to remove, the more they seemed to spread the infection." 108 Huggarde's use of the myth of Hercules and the Hydra was intended not only to describe the many faces of heresy but also to prove "truth" would be the victor. Martyrdom presented an obstacle to the Catholic conquest of England, a minor speed bump. But for this to take place would require the extermination of all English Protestants.

As the execution of the Edwardian officials spread throughout England and with them martyrdom and martyr veneration, the Marian anti-martyrologists were faced with a rationalization of martyrdom. The first question asked by Marian anti-martyrologists was: Why would English subjects choose heresy and death over the simple and safe

\footnotetext{
${ }^{107}$ Huggarde, Displaying of Protestants, 24.

${ }^{108}$ Mark Byford, "The Birth of a Protestant Town: the Process of Reformation in Tudor England," The Reformation in English Towns, Patrick Collinson and John Craig, eds. (New York: St. Martin Press, 1998), 33.
} 
conformity and Catholicism? This invariably led to the question, why were these Protestants or "false" Christians assuming the role of a martyr, or why were they associating themselves with the "true" martyrs of the early Church? Huggarde comments that these Protestants "dare be bold to compare themselves to the martyrs of the primitive Church. To whom they are nothing like." Huggarde adds that the martyrs of the true Church professed God's "truth" and that the Protestants were making "God's truth to be divers." 109 Martyrdom was not for Protestants to apply as a defense for heresy. This created counter martyrological accounts or anti-martyrologies. French Reformation historian Donald R. Kelley, discussing the massacre of French Protestants at St. Bartholomew, presents the necessity and rationalization for anti-martyrological works. He says of the French Catholic reaction, it was to "create a kind of counter-mythology about heretics and, ultimately, an anti-martyrological tradition."110 Marian antimartyrologists employed this same type of "counter mythology" to demonize the Protestants martyrs and refuted the qualities and aspects of martyrdom that Protestant martyrological accounts were based on. Marian anti-martyrologists had many explanations for an English subject choosing death over conformity.

Huggarde presented those who went to their death as ignorant and incapable of comprehending God and the "true" faith. He presented Protestants as faithless and ignorant men and women whose beliefs were like feathers "tarted about with any blast of new doctrine."111 The reality of Protestantism, to Huggarde, was not that it was a thriving and threatening heresy but just another heterodox belief that attracted culpable and

\footnotetext{
${ }^{109}$ Huggarde, Displaying of Protestants, 81.

${ }^{110}$ Donald R. Kelley, "Martyrs, Myths, and the Massacres: The Background of St. Bartholomew," The American Historical Review Vol. 77, No. 5 (December, 1972), 1329.

${ }^{111}$ Huggarde, Displaying of Protestants, 79.
} 
ignorant people. Protestantism, like many heresies of the past, converted easily misled people, and it, like all heresies of the past, would be doomed because of the ignorance of its followers. As misled people, Protestants hungered for any knowledge, despite its evils or ramifications. Anti-martyrologies considered heretics as dangerous--but ultimately, only to themselves. They ingested any knowledge, were wholly captured under its spell and cared "not to spend the rest of their lives in folly." 112 Protestants' folly was that they celebrated death as though they were rightfully obeying God, but they were not glorified in death but doomed.

Anti-martyrologists argued that the fate of a Protestant was not in the hand of the Crown but a choice that Protestants made. English Protestants could choose to recant and live peacefully or choose to be executed as heretics. Huggarde asked, "How many do we see for lack of grace, willfully, without appearance of God or man, precipitate themselves into a temporal fire, without any respect or due consideration of the life to come." Huggarde asked his readers to recall the number of men and women they had witnessed accept death willfully and dutifully. Not only were the Protestants ignorant of the "true" faith but also ignorant of one of Christianity's most fundamental principles of the afterlife. The fires the Protestants faced were not the soul cleansing fires of martyrdom, and would not be the last they would face. Their act of nonconformity and blasphemy against the Church guaranteed the Protestants an eternity in the fires of hell. What emerged out of this argument was the inability of either the English Catholics or Protestants to accept the role cast upon it by the other. Marian writer John Gwynethe

\footnotetext{
${ }^{112}$ Huggarde, Displaying of Protestants, 80.

${ }^{113}$ Ibid, 35.
} 
described this situation, when he wrote "there is no heretic, that can tell whether or not he be a heretic or not."114

The inability of either side to accept the role given to them, whether persecutor or heretic, developed from the reformation and the emergence of two powerful Christian sects. Catholics and Protestants were arguing and defending a Christian "truth;" Catholics defending the "true" Church and Protestants dying in order to preserve and glorify the "true" religion. As Protestants continued to choose death over conformity, Marian anti-martyrologists attempted to prevent them from describing their dead as martyrs. There was a fundamental Christian structure for constructing martyrs that glorified key moments in a martyr's trial. Martyrologists relied on the last moments of a martyr's life as an exemplary tale of bravery and devotion. Marian anti-martyrologies used this same structure as a blueprint for their refutations of Protestant martyrs. The last moments of a Protestant martyr's life were presented as nothing to glorify but as further proof of the Protestant's manipulations and heresy.

The final moments of a martyr's life, moments used by Protestant martyrologists to memorialize and glorify the devotion and bravery of their dead, were used by antimartyrologies as evidence for refutation. Protestants revered their executed as devoted Christians reveling in death over recantation. They faced death with a bravery and zealousness inspirational to all. Gregory calls this reliance on a person's "constancy in death" a "criterion for telling true from false martyr."115 However, Huggarde viewed this fortitude in the face of death as something uninspiring. Huggarde stated, "If the stoutness of death be a just cause to prove a martyr then many who have denied Christ were

\footnotetext{
${ }^{114}$ Gwynethe, Declaration of the State, 53.

${ }^{115}$ Gregory, Salvation at Stake, 323.
} 
martyrs."116 Anti-martyrologists, such as Huggarde, still hoped that reason would work with Protestants and their sympathizers. Huggarde was urging English subjects to recall history, whether it be local or international events, and they would find examples or men, Christian or not, who displayed the same strength in the face of death as the English Protestants. The act of dying well was not something to be celebrated or mimicked but something evil.

Huggarde considered the act of dying well, evidence vital to Protestant martyrologies, not as bravery, but as something evil granted to them by the devil. Huggarde wrote, "the devil whose martyrs they be, doth always instruct his darklings to follow his ragging steps." 117 English Protestants, inspired by the devil, were, instead of dying a glorious death, treating death as a "jolly recreation, or banquet, to some belly chore or to a play."118 Huggarde viewed the Protestants' choice of death and their treatment of death as something insincere and impure. He explained to his readers that fear in the face of death was not something cowardly or unchristian, pointing out that even "Christ was afraid of death himself." 19 Jesus' death and the death of the early Church martyrs were unselfish acts granted to the world. Huggarde described the Protestant martyrs as dying for themselves. Instead of displaying grace, the Protestants lacked the modesty, charity, patience, and love that was exemplified by Christ and the early Church martyrs. Huggarde believed that Protestants were not "true" martyrs since they died for "self love" which was the "only cause of martyrdom for our martyrs." 220 By choosing death, publicity and legacy, Protestants did not die as "true" martyrs but purely

\footnotetext{
${ }^{116}$ Huggarde, Displaying of Protestants, 76.

${ }^{117}$ Ibid, 77.

${ }^{118}$ Ibid, 69.

${ }^{119}$ Ibid, 78 .

${ }^{120}$ Ibid, 78.
} 
to be remembered. Gregory calls this aspect of anti-martyrological writing a "two-edged sword." It was dangerous to restructure resolute suffering as an "insufficient marker of martyrdom," ${ }^{21}$ because it invited rivals to challenge the resolve and bravery of one's own martyrs. However, Marian anti-martyrologists were not concerned with counter claims or Protestant attacks, only that the English subjects understood which side represented "good" and which side represented "evil."

How one would be remembered was the driving force of the Marian antimartyrological and martyrological accounts. The history of the times was being written by two competing factions: the anti-martyrological and the martyrological. English historian Marcia Lee Metzger understood this battle for history when she wrote that "Mary's government, like its predecessors understood the need for creative rewriting and censoring of history." 122 Evidence and arguments were presented by Marian writers and anti-martyrologists, but it was ultimately up to the reader and witness of the events to determine which accounts to hold as the absolute truth. Both defended a legacy that was to be accepted by England. Anti-martyrologists presented Mary as an ordained monarch, using her throne to resurrect and protect the English Church. English Catholics were the soldiers in a crusade to purify the Church and protect it from heresy. They were not brutal persecutors, condemning and executing innocent Christians. The Crown and English Catholics were acting to protect their monarch and their Church.

Martyrologies attempted to undo and disprove the perception cast by the antimartyrologies. The persecutions were defined as brutal, evil and ungodly. Persecution was an attempt to destroy God's religion, and just as anti-martryologists defined heresy as

\footnotetext{
${ }^{121}$ Gregory, Salvation at Stake, 325.

${ }^{122}$ Marcia Lee Metzger, "Controversy and 'Correctness:' English Chronicles and the Chroniclers, 15531568," Sixteenth Century Journal, Vol. 27, No.2 (Summer, 1996), 440.
} 
God-granted, Protestants justified the persecutions as divinely inspired. The Marian persecution was a test of the true believers, one that would separate the devoted from the spiritually weak. When Mary died in 1558, the conflict was resolved as Protestant Queen Elizabeth I took the throne of England. The martyrologies would be the accounts remembered, glorified and expanded upon as the absolute truth of Mary's reign. Religion, or at least the Christian denomination of England, would once again be determined by a new monarch. But during the reign of Elizabeth, martyrologies would be written that attributed the victory of Protestantism not only to Elizabeth's accession but also to the martyrs of Mary. These men and women had inspired, recruited and maintained English Protestantism with their deaths. 


\section{FOXE'S MARTYROLOGY}

When Queen Mary died in 1558, so did the Protestant persecutions and the integrity of those documents and materials used to defend them. Queen Elizabeth took the throne in the same year, and her accession ended England's tumultuous battle for a national religion. Elizabeth ushered in a religious settlement and peace that saw no persecution for two decades, setting out to end the religious persecutions that had polarized England for the last decade. She enacted legislation to end the religious persecutions that had polarized England for the last decade. Her answer was the Act of Uniformity, legislation that united the Church of England into one Church and one practice. ${ }^{123}$ The Act of Uniformity removed the edge of superiority or political domination by either group and for a brief period, they, while not satisfied, were calmed with a religious settlement. Parliament followed the Act of Uniformity with legislation that reinforced the religious peace of England, namely, the Oath of Supremacy and the Assurances of the Queen's Royal Powers. ${ }^{124}$ All loyal English subjects were required to attend the services of the Anglican Church or face the penalty of fine, imprisonment or charged with treason. Elizabeth successfully created an environment free from religious persecution, but she could not quell the memories and resentment harbored from the Marian persecutions.

\footnotetext{
${ }^{123}$ Elliot Rose, Case and Consciousness: Alternatives Open to Recusants and Puritans Under Elizabeth I and James I (London: Cambridge University Press, 1975), 11

${ }^{124}$ Rose, Case and Consciousness, 12.
} 
The persecuted Protestants of Marian England no longer constituted the minority under Elizabeth, and they now had the power and the ear of the Queen. By the winter of 1558-1559 most of the exiled Protestants had returned to England, carrying with them a resentment and phobia of English Catholics. ${ }^{125}$ As Protestants returned and became the majority in England, the roles that had existed in Marian England would be reversed. Catholics would be segregated, forced into recantation to ensure the maintenance of peace, but not persecuted. As Protestantism dominated England, so would it dominate English history. Under Elizabeth the Marian anti-martyrologies that supported the actions of the persecutions would be discarded, would become merely propaganda of an "evil time" and would need to be clarified. Catholics had become the hated and the hunted.

Thomas Stapleton wrote in 1565, as English Catholics were slowly growing into their new roles in England, that the Elizabethan settlement was a "great morsel indeed, and very uncourteously fed to you." 126 Protestant revisions were manifestly warranted to counter the anti-martyrologies and to grant the Protestants of Marian England their final identity, as martyrs of the "true" Church. Elizabethan Catholics were force-fed their crimes of persecution under Mary and they would permanently take on the label of brutal persecutors. The roles and labels so controversial during the Marian persecutions would be cemented as John Foxe's Acts and Monuments circulated England in 1563.

Most importantly, Foxe's Acts and Monuments created and promoted Protestant solidarity in England. Foxe's comprehensive martyrology linked Protestant martyrs to the martyrs of the early Church, martyrs whose deaths were at the hands of heretics and whose deaths carried Christianity from its oppressive past to present glory. Kelley says

\footnotetext{
${ }^{125}$ Morey, Catholic Subjects, 20.

${ }^{126}$ Stapleton, Fortress of Faith, 2.
} 
martyrologists, such as Foxe, promoted this connection in order to "intensify the impression that they were recapitulating the experiences of early Christian--confronting the same style of interrogation, the same inseparable charges of blasphemy and sedition, and the same sorts of repression and punishment."127 The Marian martyrs and the Protestants of Elizabethan England were no different in Foxe's eyes. All were "baptized in the same belief, and believe the same articles of the creed as ye do, hearing the same God, the same Christ and Saviour." "128 Foxe reminded England that common beliefs were not the only connection to the Marian martyrs.

Foxe's readers, undoubtedly, were related to someone who had died, were friends, neighbors, or acquaintances or witnessed the death of one of the many martyrs with their own eyes. The martyrs of the Marian persecutions represented all segments of England; they were "old, young, children, infants, new born, married, unmarried, wives, widows, maids, blindmen, lame men,..., of all sorts of ages, of all degrees; lords, knights, gentlemen, lawyers, merchants, archbishops, priests, ministers, deacons, laymen, artificers." education, and beliefs. Protestantism under Mary came to represent in England a united England or a cause with the ability to unite all of England under one banner. Foxe described to England the importance of this solidarity, asserting that what the Marian persecutions proved was that common English subjects--the uneducated, women, and the nobility--were urged by their "true" religious convictions to resist, and motivated to display grace, steadfastness, and bravery in the face of death. These were the traits of the early Church martyrs and most importantly, the martyrs of the Marian persecution.

\footnotetext{
${ }^{127}$ Kelly, "St. Bartholomew," 1329.

${ }^{128}$ John Foxe, "Pope's Proceedings," Acts and Monuments: Volume One, xxvii

${ }^{129}$ John Foxe, "Papists," Acts and Monuments: Volume One, xii.
} 
Foxe's Acts and Monuments completed the puzzle of the Marian persecutions. In opening the Acts and Monuments, Foxe addressed a letter to the Queen in which he explained the importance of rewriting and reacclimating England with the Marian persecutions. Foxe explained to the Queen that English society was "simple and unlearned, yet not unapt to be taught if they were applied."130 Foxe's mission was to be teacher and instructor, and his evidence or curriculum was the martyrology of the Marian Protestants. The majority of Protestants had recanted under Mary in order to protect themselves, their families and their property from the persecutions. This was the audience that Foxe addressed, now the majority in Protestant England and the "simple and unlearned." Many of the Elizabethan Protestants had been Marian Catholics--Catholics who had supported the persecutions or secretly sympathized with the Protestants. Either way these men and women represented a segment of English society that needed reeducation and reassimilation into a Protestant kingdom.

Catholic writings and Catholic anti-martyrologies that incriminated the Marian Protestants were to be unlearned with the aid of Foxe's Acts and Monuments. All that was written under the reign of Mary was "false;" it was propaganda written in order to defile the Protestant martyrs. Foxe's Acts and Monuments was to be the final indoctrination of England. It would officially counter and refute the propaganda and the writings of Marian England, those supported by Marian Catholics. Foxe described the writers of Mary's reign as men who "delight in untruths, and have replenished the whole Church of Christ with feigned fables, lying miracles, false visions and miserable

\footnotetext{
${ }^{130}$ John Foxe, "Letter to the Queen," Acts and Monuments: Volume One, vii.
} 
errors." ${ }^{131}$ Foxe's audience, the Queen's subjects, was in need of reeducation. Foxe described them as an

ignorant flock of Christ committed to your government in this realm of England, whom as they have long been led in ignorance, and wrapped in blindness for lack especially of God's word,...I thought pity but that such should be helped, their ignorance revealed and simplicity instructed. ${ }^{132}$

Foxe was single-handedly rewriting the ecclesiastical history of the realm, a history that would prove critically important to the unity of England and English Protestantism. Foxe had written a history, a martyrology deemed so important by himself that it "ought not be separated from the teachings of Christ." 133

In the process of glorifying Protestantism, connecting it with early Christianity and memorializing the acts of English Protestants, Foxe was vilifying Catholicism. He helped create or at least remind England of the brutality and evilness of Catholicism, writing that the English Catholics had operated under a "mad rage...of furious cruelty, in spilling the blood of such an innumerable sort of Christ's holy saints and servants."134 Foxe blamed not just Mary but Catholicism in general for the death of the Protestant martyrs. He asked the Catholics, who had willfully persecuted their fellow Englishmen and claimed to have only been following the law, was it the "law of God or the law of man?"135 Foxe believed England deserved accountability, not excuses, from the Catholics of England. In Foxe's retelling of the Marian persecution, every Catholic shouldered the blame for the death of "so many silly and simple lambs of

\footnotetext{
${ }^{131}$ John Foxe, "Letter to the Queen," Acts and Monuments: Volume One, vii.

${ }^{132}$ Ibid, viii.

${ }^{133}$ Ibid, viii.

${ }^{134}$ John Foxe, "Papists," Acts and Monuments: Volume One, xii.

${ }^{135}$ Ibid, xiv.
} 
Christ's...without mercy, without measure, without all sense of humility."136 Catholicism's role as persecutor was revitalized by Foxe, further vilified within the martyrologies of the Marian Protestants and used to generate a paranoia and anxiety about the Catholic subjects of England.

Despite Foxe's contempt and resentment for Catholicism and the spread of Acts and Monuments across England, Catholicism had a peaceful first decade of Elizabethan rule. Elizabethan Catholics accepted the decrees of the Crown and lived relatively peacefully during the first decade of the Elizabethan reign. The English Catholics did not protest the Anglican Church and the Elizabethan settlement because the Church retained many of its Catholic features. The buildings, the hierarchical structure, and the parish as the center of the Church community went basically untouched. ${ }^{137}$ Enforcement of the newly enacted Uniformity laws was very lax, the Oath of Supremacy was not widely implemented and regulations and fines for nonattendance were not meted out. ${ }^{138}$ Due 10 the laxity of the Elizabethan settlement, Catholics were not faced with conscientious objections to the Anglican Church. During the first decade of Elizabeth's reign, problems arose between Protestants and Catholics only when Protestants accused Catholic neighbors of nonconformity. ${ }^{139}$

\footnotetext{
${ }^{136}$ John Foxe, "To the Persecutors of God's Truth, Commonly Called Papists," Acts and Monuments: Volume One, xii.

${ }^{137}$ Pritchard, Loyalism, 4

${ }^{138}$ Pritchard, Loyalism, 3.

${ }^{139}$ Caroline Litzenerger, "The Coming of Protestantism to Elizabethan Tewksbury," Reformation in English Towns, Patrick Collinson and John Craig, eds. (London: MacMilliam Press, 1998), 29.
} 


\section{ELIZABETHAN PERSECUTIONS}

The Elizabethan persecutions demonstrate the accepted method of introducing, explaining and defending the persecutions to a nation as displayed in the Marian persecutions. Anti-martyrologies also proved to be the final answer and defense of the persecutions. What separated the Marian and Elizabethan persecutions was that Elizabeth broke a twenty year religious peace with her persecutions, she attempted to persecute a religious group for political reasons and faced written and distributed martyrological accounts. The Crown was attempting to persecute Catholics based on a charge of treason, based on a fear of foreign Catholicism. Despite these drastic differences, the Elizabethan persecutions followed the same blue-print as Mary's: introduce and explain to the public the nature of the persecutions, define those who would be persecuted and why, and finally rely upon anti-martyrologies to counter the martyrdom created from the persecutions. The Elizabethan persecussions presented England with a new cycle of persecutions, martyrologies and anti-martyrologies. The peace would be broken in 1581, a peace that English Catholicism had enjoyed for twenty years.

In the early years of Elizabeth's reign recusancy, or refusal of English Catholics to attend Anglican services, posed a minor problem. ${ }^{140}$ The lax enforcement of the settlement allowed Catholics to take part in the Anglican services, yet retain Catholic

\footnotetext{
${ }^{140}$ Pritchard, Loyalism, 4.
} 
practices in private. Adrian Morey, Elizabethan Catholic historian, believes this resulted in English Catholics "developing little inclination to revolt against the Elizabethan settlement."141 Another crucial reason for the lack of Catholic protest and virtual assimilation during the first decade of Elizabethan rule was the inability of the English Catholics to form any leadership or draw the attention and interest of Rome. ${ }^{142}$ The majority of the Catholic leadership was exiled to the continent and this lack of a head contributed greatly to the peace of England. Pritchard says, "Ironically enough, it was almost certainly during this period of relatively little active persecution that the Catholic Church lost most of its hold on the English people." ${ }^{43}$ Without persecution to unite and solidify an active Catholic resistance to the Elizabethan Protestantization of England and no apparent leadership to organize one, the first two decades of Elizabeth's reign were a time of peaceful settlement.

While Rome had virtually abandoned the Catholic subjects of Elizabeth throughout the 1560 's, its attention and that of the entire Catholic community would refocus and reshape the somewhat peaceful existence of English Catholics for the remainder of the Elizabethan reign. The relative peace, or at least the accepted situation of England, was fractured but not broken in 1566, as newly elected Pope Pius V spoke out against English Catholics attending heretical services. ${ }^{144}$ Pius V decreed that the "true" Church forbade these services and that any Catholic attending would be denying the "true" faith. ${ }^{145}$ Immediate fear and paranoia, which had been quieted but ever present, were sparked in England and turned upon the English Catholic community. By March

\footnotetext{
${ }^{141}$ Adrian Morey, Catholic Subjects, 42.

${ }^{142}$ Ibid, 45.

${ }^{143}$ Pritchard, Loyalism, 4.

${ }^{144}$ Morey, Catholic Subjects, 46.

${ }^{145}$ Dillon, English Catholic Comminity, 11.
} 
1569 rumors were circulating that Pope Pius V was orchestrating a joint invasion by Catholic powers. ${ }^{146}$ In 1570 , this concept of a monolithic Catholic threat reached its height and would become a permanent fixture of Elizabethan England. Pope Pius V issued the papal bull Regulas in excelsis, excommunicating Queen Elizabeth and deposing her subjects. ${ }^{147}$ Thomas believes that this papal bull "virtually amounted to a papal declaration of war and it ended the dozen years of comparative calm." ${ }^{148}$ What this papal bull meant for English Catholics was that the government now had license to consider its Catholics subjects as threats to the English Crown and that the labels that had rested since the reign of Mary would resurface and be reenergized to the extent that Catholic paranoia enveloped and drove England for the decades to follow. ${ }^{149}$

As European Catholics began refocusing their sights on England, the xenophobia already present coupled with the fear of English Catholic treachery, spurred the Elizabethan administration to deal with what they perceived as a threat to the nation's stability. In 1569, Elizabeth executed Mary Queen of Scots, a Catholic, for treason against the Crown, faced northern rebellion and the resurgence of a dangerous rivalry with the Catholic power Spain. Since the papal bull Regulas in excelsis declared her "subjects absolved of their obligation to her," ${ }^{150}$ Elizabeth feared this threat to civil disobedience would culminate in an English and European combined Catholic conspiracy. ${ }^{151}$ The fragile peace that had existed was broken as anxiety and fear of English Catholics spread across England. Grouped with Roman Catholicism, the English

\footnotetext{
${ }^{146}$ Morey, Catholic Subjects, 56.

${ }^{147}$ Ibid, 55.

${ }^{148}$ Thomas, D. Aneurin, ed. The Welsh Elizabethan Catholic Martyrs: The Trialil Documents of Saint Richard Gwyn and of the Venerable William Davies (Candiff: University of Wales Press, 1971), 11. ${ }^{149}$ Adrian Morey, Catholic Subjects, 58.

${ }^{150}$ Pritchard, Loyalism, 4.

${ }^{151}$ Adrian Morey, Catholic Subjects, 82.
} 
Catholics were publicly demonized, and they began to turn away from the Anglican Church. Recusancy began to spread among the English Catholic communities and they began withdrawing from a society that was growing more hateful and fearful of their presence. $^{152}$

In 1571, the Elizabethan administration passed its first anti-Catholic legislation. This act prohibited Catholics from serving in the House of Commons. Three acts followed that confronted the newly perceived threat of Catholicism to English stability. The Treason Act prohibited any writings or assertions that declared Elizabeth an unlawful Queen or described her in any derogatory terms. The second act prohibited papal bulls or Catholic articles from having any jurisdiction in England, and the third focused on the English Catholic exiles. ${ }^{153}$ The threat of international Catholicism had transformed the English Catholics into a dangerous minority within England and although the majority of this legislation was directed at external Catholicism, English Catholics were the ones who suffered. By the late 1570 s, based on both a real and an exaggerated Catholic threat in England, fear and anxiety of foreign Catholicism encircled the island and by the 1580s royal legislation and judicial action would be implemented to maintain the threatened peace.

The 1580s marked the official end of the religious peace in England, as paranoia of Catholicism reached its zenith and the Catholic eye of Europe was turning back toward England. English Catholics had remained a minority since the accession of Elizabeth due their lack of leadership and organization. In 1580 the Catholic seminaries of Europe, ones that harbored exiled English Catholics, attempted to fill the vacuum of leadership

\footnotetext{
${ }^{152}$ Aneurin, Welsh Elizabethan, 18.

${ }^{153}$ Ibid, 60 .
} 
present within English Catholic communities. In 1580, only several hundred priests were secretly operating in England, but during that year Jesuit ministers arrived with the intent of ministering to Catholicism's forgotten flock. ${ }^{154}$

The Jesuits' arrival in England in 1580 sparked a minor Catholic renewal, most directly in recusancy, but it also provided further evidence to English suspicion and paranoia about the loyalty of English Catholics. Adrian Morey believes it was the arrival of the Jesuits that forced the Elizabethan Crown to realize that "Catholicism was not likely to die away for the lack of priests and that in fact a revival was in progress."155 Fearful and threatened by the possibility of English Catholic organization and growth of competent Catholic leadership, the Elizabethan Crown began covert searches for Jesuit priests and Catholic resuscancy. ${ }^{156}$ While the Jesuits inspired a slight revival in English Catholicism, they also marked an end to the laxity of the enforcement of the Elizabethan settlement.

The Jesuits and Catholic missionaries entered an England that had become comfortable with the situation of its minority Catholics. Elizabethan historian Christopher Haigh correctly argues that it was no longer a Catholicism "which stresses union with Rome and conscious rejection of the heretical Church of England." ${ }^{157}$ Morey agrees that it was a Catholicism that had been "cut off from the European influence and had missed the rekindling of the Counter Reformation."158 The Jesuits and Catholic missionaries represented change in a nation that for twenty years had enjoyed stability. The Catholic communities to which the Jesuits and missionaries traveled met the Jesuits

\footnotetext{
${ }^{154}$ Pritchard, Loyalism, 5.

${ }^{155}$ Adrian Morey, Catholic Subjects, 62.

${ }^{156}$ Dillon, English Catholic Community, 15.

${ }^{157}$ Christopher Haigh, "The Continuity of Catholicism in the English Reformation," 40.

${ }^{158}$ Morey, Catholic Subjects, 12.
} 
and priests with an initial response of fear and suspicion. It was felt that they would cause harsher or even violent persecutions upon the Catholic community. ${ }^{159}$ This fear of the English Catholics developed into a reality in 1581 as the Crown had determined upon a response to the Jesuits and Catholic missionaries. Change was not wanted in Elizabethan England, especially from the Crown, that was driven by a fear of foreign Catholicism.

Persecutions of the Jesuits would not begin until 1581. From 1580 till 1581, the Crown focused on the labeling all Jesuits and Catholic priests in England as conspirators. The Proclamations of July 1580 and January 1581 outlined the course that the Elizabethan administration had determined for the Jesuits and Catholic priests. The proclamations' importance, like that of William Barlow and John Proctor to the Marian persecutions, was to label and define the nature of nonconformity. These two proclamations, while preceding the persecutions, were basically anti-martyrological. Nonconformity within Elizabethan England would be defined as treason. Religion would be removed as a reason for the persecutions. The royal proclamation of July 15,1580 , was a statement of offense against the Jesuits and Catholic priests. It warned them that they were considered traitorous by the Crown and that Elizabeth and her ministers were not fooled by their proposed evangelical intentions. Ultimately, it was a warning to England that traitors were assimilating into the population.

Elizabeth and her administration chose treason as the applicable crime for the Jesuits and Catholic priests. The royal proclamations and anti-martyrological writings produced during the Elizabethan reign profess a deep-seated fear of foreign Catholicism. It is undeniable that the Crown and much of Protestant England were anti-papists and

\footnotetext{
${ }^{159}$ Haigh, "Continuity of Catholicism," 38
} 
their beliefs, fear, and decisions were directed by their hatred and fear. Michael Questier says that "anti-papistry was an aspect of mainstream Elizabethan politics and administration," and this multiplied by the rumors and fears of a foreign Catholic invasion led by the Pope, generated the atmosphere in which the Jesuits and Catholic priests entered. With the appearance of the Catholic missionaries it was feared that English Catholics would disobey and rebel against Elizabeth. The Jesuits and Catholic priests represented a "fifth column" within the English Catholic community. The Crown and all of England, so accustomed to toleration of the English Catholics, now had reason to fear the English Catholic community.

The Jesuit and Catholic missionaries' leadership had presented itself for English Catholics, coincidentally, at a time of heightened rumors and fear of foreign Catholicism. Questier comments that Elizabeth and her administration "never believed they were they were dealing with just a few deranged conspirators," 160 but with evangelical men determined to unset the Queen and England's Protestants peace. The seminary students who appeared in England were a result of the "feeder" schools in England that sent young men to the continent for seminary training. ${ }^{161}$ The European seminaries were "institutions under papal patronage and financed partly by the Pope and Spain."162 Elizabeth and her administrators believed that the rumors of a foreign Catholic takeover had now become fact and England was now in danger internally. All of these biases and reasons factored into the Crown's decision to break the peace that had existed in England for over twenty years and the reason treason was chosen as the charge.

\footnotetext{
${ }^{160}$ Michael Questier, "Practical Antipapistry," 379.

${ }^{161}$ Haigh, "Continuity of Catholicism," 54.

${ }^{162}$ Pritchard, Loyalism, 8.
} 
The presence of Jesuits and Catholic priests, accompanied by a minor renewal of English Catholicism, had to be rationalized and explained in terms that England could understand and accept. The missionaries were actually criminals, internal threats to England, and to the peace and stability that a generation of English men and women had become accustomed. The proclamations explained to England that these men were representatives of the "Pope, the King of Spain, and some other princes" who were "accorded to make a Great Army to invade this realm of England." 163 The danger abroad had been transplanted and uncovered in England in the form of missionaries. The proclamation described England as a nation infiltrated by enemies who were loyal to the "City of Rome and there in have falsely and traitorously sought and practiced by all means possible to irritate, all estates against her majesty and the realm."164 The Crown was accusing Jesuits and Catholic priests of disloyalty and dishonesty. The Jesuits and Catholic priests made a choice of loyalty to the Pope and Catholicism instead of adopting the rules and regulations of Elizabethan England. These men now had chosen to advance upon England with the intention of turning Elizabeth's subjects against her. No actions were outlined in the proclamation of 1580 , but lines of loyalty were drawn. The Jesuits and Catholic priests represented the monolithic Catholic threat that terrified England.

In 1580 , the death penalty was levied, but sparingly applied, against the English Catholics accused of recusancy and treason toward England. Although not often used, the enactment of the death penalty proved that Elizabeth considered this threat to be real and worthy of capital punishment if discovered by the Crown. The financial penalties enacted from previous legislation still provided a harsher and a more peaceful deterrent to

\footnotetext{
${ }^{163}$ Royal Proclamation of July 15, 1580, “Against Rebels" (Christopher Baker, 1580), 1.

${ }^{164}$ Royal Proclamation 1580, 1.
} 
the disloyalty of English Catholics. Failure to meet the payments for recusancy meant the loss of all goods and nearly two-thirds of family lands. ${ }^{165}$ But these financial penalties and lenient discipline were not considered sufficient means of dealing with the internal threat that the Jesuits and Catholic priests presented. It was believed by the Crown that international Catholicism was attempting to fight the Protestantization of its former empire, and England would be a battlefront. It was obvious that an international Catholic threat had materialized in England. Catholic missionaries had appeared in England to reinvigorate a Catholicism that was all but dead, that was out of sight, out of mind. The proclamation of January 1581 detailed the transition of England from toleration to persecution.

This proclamation was entitled "A Proclamation for the revocation of students from beyond the seas, and against the retaining of Jesuits." Whereas the Proclamation of 1580 outlined the threat Jesuits and Catholic priests posed to England, this January 1581 proclamation identified English men and women who harbored the Jesuits as dangerous to the realm. Apparently the threats outlined in the 1580 proclamation were not heeded, and Jesuits and Catholic priests continued to immigrate into England and be accepted by English communities. The true intentions of the Jesuits and Catholic priests were outlined as two-fold. First was ministry, but secondly and most detrimental to England was the spreading of treason.

The 1581 Proclamation made it clear that treason and religion were separable. The Jesuits' true intentions were to "train and nourish them (English subjects) up in false

${ }^{165}$ Morey, Catholic Subjects, 68. 
and erroneous doctrine." ${ }^{166}$ Through a missionary front, the Jesuits and priests were determined to relieve the English subjects of their "natural duties unto her Highness, as their prince sovereign and have been made instruments in some wicked practices tending to disquiet the realm." 167 This proclamation was intended to be a revelation to the English subjects, or a warning. Elizabeth warned her English subjects, especially English Catholics who housed and maintained the missionaries, that the missionaries they accepted into their home and communities intended to destroy the stability of the realm. English Catholics, who had lived a relatively peaceful existence during the reign of Elizabeth, were urged to consider the purpose of their fellow bedmates and the danger this not only presented to England but to the safety of English Catholics who did not comply.

The proclamation of 1581 laid the framework for the Crown's charges that disloyalty was being shrouded or concealed within religion. It was a case of treasonous activities being covered by missionary work. This debate as to the true intention of the Jesuits and Catholic priests was the primary debate of the Elizabethan persecutions. How should the Jesuits and Catholic priests be defined, as traitors or martyrs? The two sides of the debate relied upon either the anti-martyrological evidence presented by the Crown and anti-martyrologies, or the martyrologies of the English Catholics. The Crown cried treason and the English Catholics cried religion. Whereas Mary's persecutions did not separate treason from heresy or politics from religion, the persecution of Elizabeth intended to do just that. Treason and religion in Elizabethan England became entirely separable, or at least separable to a Crown attempting to avoid martyrdom. Much like Sir

\footnotetext{
${ }^{166}$ Royal Proclamation of January 10, 1581, "A Proclamation for the revocation of students from beyond the seas, and against the retaining of Jesuits (NP, 1581), 1.

${ }^{167}$ Royal Proclamation 1581, 1.
} 
Thomas Wyatt, the Catholic missionaries were guilty of deception and of creating a ruse concealing treason within religion. The question when observing the Elizabethan persecutions is did this work? Were people stirred into opposition and defense of the persecutions?

Royal Proclamations proved a powerful tool of the Elizabethan persecutions, especially in defining the grievance the Crown held against the Catholics and the threat they posed to the realm. The Jesuits and Catholic priests were labeled as traitors and the public, already harboring thoughts of a monolithic Catholic conspiracy, were incited to support the Crown in defending England. What England received from the Crown, via the proclamations, was an internal security report. As the Crown stated and much of England truly believed, England was steadily being infiltrated by Catholic terrorists costumed as missionaries. Elizabethan historian Frederic Youngs, Jr., argues that the proclamations also gave the Elizabethan administration a means to make new laws. Youngs says, "when current practices seemed to threaten the good order of the commonwealth, proclamations defined those practices to fall within the scope of already existing law."168 As can be seen in the difference in the 1580 and 1581 proclamations, the Crown used the proclamation of 1581 to incriminate any English subject who harbored or aided the Jesuit and missionary criminals. These royal proclamations allowed a xenophobic England to latch onto its fear of the outside, heightened by a threat from within. Elizabeth and her administration prodded public opinion to such a level of distrust that all foreigners were perceived to be a part of the Catholic threat to England.

By April of 1581, this anxiety and hatred had reached such a level that the Crown was forced to issue a Proclamation entitled, "For good treatment of the French ${ }^{168}$ Youngs, Jr., "Definitions of Treason," 675. 
Ambassador."169 The national level of anxiety, either rampant and out of the Crown's control or fully within the Crown's plan of action, had grown so intense that English men and women could not distinguish between foreigners the Crown identified as allied and those identified as enemies. The realm of England had moved into a state of paranoia, urged on by the Crown and its perception of a monolithic Catholic threat. In 1581, Elizabeth began open persecutions of the Jesuits and Catholic priests within England and ushered in a new era of English martyrdom.

In December 1581, Edmund Champion and twelve other Catholics were arrested, tried and executed as traitors. The Elizabethan Crown had determined that these men were representatives of Rome and foreign Catholic nations in England. All were hanged, dismembered, and quartered, the death of a traitor. ${ }^{170}$ Martyrdom and the power of martyrologies were revived from their dormant state within England. Although the royal proclamations had intended to remove religion from the persecutions, they could not remove martyrdom. Catholics would glorify their dead as martyrs, and the Crown would continue its present course of trying to remove religion from the persecutions and in the process attempting to deny Catholics martyrdom.

The Elizabethan persecution and anti-martyrologies that defended it were driven by one simple purpose: to paint the persecutions and executions as political purges enacted in order to protect the realm from traitors, not as the religious persecution of heretics. Comparatively, Mary's persecutions were easier to defend; they had a more solid footing to rely upon. In Marian England, a heretical group was being executed for religious reasons and martyrdom claimed by the persecuted as a result of the executions.

\footnotetext{
${ }^{169}$ Royal Proclamation of April 18, 1581, "For good treatment of the French Ambassador" (NP, 1581)

${ }^{170}$ Morey, Catholic Subjects, 85.
} 
Instead of only defending itself against martyrdom, the Elizabethan government was attempting to remove martyrdom entirely from the process. The Elizabethan administration, by denying any religious purposes, was attempting to make its persecutions safe and free from any glorifications of the executed. Gregory argues that this was one way for the government to persecute without martyrdom and had been applied by Henry VIII to deny Catholics any claim to martyrdom. ${ }^{171}$ This was a grand and impossible ambition.

William Allen offered a defense of Catholicism in England and the traitorous intentions placed upon it by the Crown in 1581. Allen wrote an Apologie and True Declaration of the Institutions and Endeavors of the Two English Colleges as an attempt to reason with Elizabeth about her policy of persecution. Allen presented his fellow Catholic missionaries, not as traitors or conspirators as defined by the Crown, but as loyal English subjects. According to Allen, these missionaries, despite their Catholicism, displayed an unfaltering loyalty to the Queen. This would become the common plea used by Catholic martyrologists as evidence that the persecutions were carried out because of religion, not treason. It would also define the last moments of a Catholic martyr's life. Whereas Foxe's descriptions of the Protestant martyrs focused on their unflinching faith and choice of death over recantation, the Catholic martyrs presented in the martyrologies displayed an unflinching loyalty, despite the Crown trying and executing them as traitors. Allen pleaded with Elizabeth to share his view of the Catholic missionaries as honorable, trustworthy and aligned with the Queen's desire for the betterment of her subjects. Allen

${ }^{171}$ Gregory, Salvation at Stake, 328. 
argued that the purpose of Jesuits' and Catholic priests' presence in England was merely to "serve God and the Church of England.",172

This duty of the Jesuits and priests to serve English Catholics was necessitated by the lack of English Catholic leadership. Ministers were needed to quench the Catholic need for leadership, and Allen urged Elizabeth and the English subjects, so radically opposed to the missionaries, to accept their presence as pastoral not criminal. Allen insisted that Jesuits and Catholic priests traveled to England for Catholics alone; Protestantism was not a concern or focal point of their ministry. Simply put by Allen, the Jesuits and Catholic priests were present in England for the "Baptism of the Religion, of faith and service of Catholics alone."173 The Catholic priests were not in England as resisters bent on inciting a religious rebellion and overthrowing Protestantism, but as ministers to a leaderless Catholic flock.

Allen presented the intentions of the Jesuits and Catholic priests as pure and nonpolitical. The Apologie also set out to appeal to the Queen and England to dismiss the constantly growing and climaxing anxiety over Catholicism. These persecutions, as observed by Allen, were a hastily drawn policy responding to an imagined and created fear. Allen asked Elizabeth and all of England to reevaluate the actions taken against the Jesuits and Catholic priests. Allen had decisively presented to the reader that the intention of the Jesuits was simply to minister to English Catholics. Now it was up to Elizabeth and her English subjects to end the unwarranted executions of the Catholic missionaries. Allen placed the fate of the English Catholics and the opinion of the Crown and England in God. Allen wrote,

\footnotetext{
${ }^{172}$ William Allen, An Apologie, 4.

${ }^{173}$ Ibid, 8 .
} 
Trusting so our lord may alter the minds of many that mistake our doings, and may turn the Queens majesty and her honorable councils ears from our calumniators, her hand of indignation from our afflicted brethren, and her heart to wanted mercy and clemency towards her own Catholic subjects. ${ }^{174}$

Allen pursued the hope that the Queen's stance against Catholicism was fleeting and could be reversed, that her ministers could be educated about the true purposes of the priests and that the anxiety developed over Catholicism could easily be washed away. All that was needed was some light cast upon the decency and loyalty of Elizabeth's Catholic subjects. Allen still considered Elizabeth a Queen that could be reasoned with and shown the error in a hastily made policy toward a nonexistent threat. However, the Elizabethan administration proved married to its persecutions of traitors and beyond any attempts at reconciliation with the Jesuits and Catholic priests.

As the Crown's stance did not waver and arrests, trials and executions against the Jesuits and Catholic priests continued, the Catholic community responded with martyrologies. In February or early March 1582, Thomas Alfield presented England with its first martyrology since Foxe's Acts and Monuments. ${ }^{175}$ Elizabethan revisionist historian Ann Dillion describes Alfield's True Report as the most significant document of printed English Catholic texts. ${ }^{176}$ Alfield, an eyewitness of Champion's execution, wrote the martyrology to glorify the death of Edmund Champion, Father Sherwin, and Father Bryan, but in dedication to the Queen. ${ }^{177}$ Compassion and reason was still the weapon of English Catholics in attempting to prove the Queen the error of her ways, but martyrologies were added. Alfield hoped to "move her Majesties heart to have

\footnotetext{
${ }^{174}$ Allen, Apologie, 8.

${ }^{175}$ Youngs, Jr., "Definitions of Treason," 685.

${ }^{176}$ Dillion, English Catholic Community, 79.

${ }^{177}$ Youngs, Jr., "Definitions of Treason," 684.
} 
compassion, may open her grave councilors eyes to see our innocence and may alter our enemies and ill informers minds to love and charity." ${ }^{178}$ Elizabeth was still not to blame for the plight of English Catholics within her realm, or at least not directly. The blame for the slandering of the Jesuits and Catholic priests and the swaying of governmental and national opinion against them lay in the hands of "informers."

These informers were, as described by Alfield, traitorously bent on convincing all of England that the presence of the Jesuits and Catholic missionaries constituted an unrelenting menace and danger to the safety of England. The real treachery committed within England, to Alfield, was the false accusations and slander committed by fellow English subjects. Informers were guilty of issuing "divers and contrary reports, falsely and maliciously bruted and published" and causing "just fear toward the glorious martyrs." 179 Worse, to Alfield, was that this was not obvious to England, especially to the Crown who had protected a religious peace for nearly two decades only to be broken over slander and erroneous reporting. In his True Report, Alfield intended to display the truth, regarding both the Catholics' intention and their loyalty to the Queen, and to refute all charges levied against the Catholics.

In opposition to the Crown's assertion that the ministry and evangelical work of the Catholic missionaries was a ruse, the martyrologies presented the Crown's charge of treason as a concealment of the truth. The Crown was guilty of the crime it placed upon the Catholics, the concealment of true intentions. The Crown was guilty of shrouding its religions persecutions behind a campaign against treason and disloyalty. Alfield presented religion as the true cause of the executions of Champion and his fellow priests.

\footnotetext{
${ }^{178}$ Thomas Alfield, A True Report on the Death and Martyrdom of M. Champion Jesuit, and M. Sherwin and M. Bryan Priests at Tiborne, the $1^{\text {st }}$ of December 1581 (NP, 1582), 15.

${ }^{179}$ Alfield, True Report, 1.
} 
Treason was an ad hoc response created by anti-Catholic English subjects who had penetrated the thinking of the Crown. The truth would be revealed in the accounts of Alfield's martyrologies. Alfield believed that all men could be shown that "those innocents suffered only for religion, for our fathers faith, and spiritual inheritance, for serving God in priestly function and duties." ${ }^{180}$ Innocent blood was being spilled within England, and Alfield described their guilt to his readers as only being guilt by consequence or association. It was treason prescribed due to slanderous conspiracy and false anxiety.

In addition to clarifying the Catholics' ministerial intentions in England and the true nature of the persecutions, Alfield emphasized the martyrs' loyalty to England within their glorifications. Like Foxe's martyrologies, Alfield's were intended to be separated from the defenses of the Crown and succeed in dispelling the accounts that described the English Catholics as traitors. Both authors emphasized the act of dying well, and Foxe and Alfield relied upon the basic martyrdom qualities of bravery, steadfastness and resolve in the face of death. Where Alfield's account differs is in what was emphasized during the last moments before the executions. Since disloyalty was the charge against the Catholic missionaries, Alfield focused on their unshakeable reverence and loyalty to Elizabeth during the martyrs' arrests, interrogations and executions. Foxe's martyrs displayed an unwavering determination to defend their faith and the "truth" of their cause; Alfield's accounts highlighted the Catholic priests' unflinching loyalty to the Queen and England.

According to Alfield, despite torture, depravity of food and water, and treatment as traitors and criminals by their own Queen and nation, Champion, Sherwin and Bryan

${ }^{180}$ Alfield, True Report , 3. 
never wavered in their loyalty to the Queen. Champion was asked which Queen he prayed for, and he responded, "for Elizabeth, your Queen and my Queen, unto whom I wish a long quiet reign with all prosperity." ${ }^{181}$ Sherwin answered the same question, saying, "I now at this instant pray my Lord God to make her his servant in his life and after this life...with Jesus Christ." ${ }^{182}$ Alfield proved the innocence of these men through their loyalty. When observing the martyrological and anti-martyrological accounts, it is important to note that the last moments of a person's life were considered to be their most truthful. ${ }^{183}$ Alfield described Champion, Sherwin, and Bryan answering their final questions as they would "answer before God." 184

The character and legacy of the Catholic missionaries was at stake. The Crown was attempting the unimaginable: removing religion from its persecutions. Alfield presented to England that these men were no more traitors to England than the most loyal Protestant subject. Each of these men was executed as a "traitor by consequence."185 Above all, Alfield reminded England that these missionaries were not devilish conspirators but "good men not acquainted with any conspiracy against our prince and country, but did suffer for the honor, peace and unity of the Church." 186 Religion was being concealed as the Jesuits and Catholic priests' crimes against England. Alfield's accounts presented these men not as traitors, but as martyrs. They were martyrs who displayed a

Piety, meekness, and modesty, so that their last protestation, washed, sealed and confirmed with their blood, so their resolute death for religion,

\footnotetext{
${ }^{181}$ Alfield, True Report, 9.

${ }^{182}$ Ibid, 12

${ }^{183}$ Dillion, English Catholic Community, 74.

${ }^{184}$ Ibid, 15.

${ }^{185}$ Ibid, 10.

${ }^{186}$ Alfield, True Report, 15.
} 
for our faith, for the Church, no doubt by God's grace shall animate and strengthen us, who remain further in the furnace of God's problems. ${ }^{187}$

What the Elizabethan persecution had been trying to avoid was cemented with Alfield's martyrology. Martyrdom could not be removed from the Elizabethan persecution and would be applied as a protest tool and evidence of the falseness of the Crown's accusations. It would be presented by Alfield to "animate and strengthen" a cause, much like Marian Protestantism used martyrdom, which was thought to be on the verge of extermination. Elizabeth now found herself locked in persecutions that would create martyrs and reliant on anti-martyrologies to protect the nature of her persecutions.

William Allen, the author of Apologie in 1581, also compiled a martyrology in 1582. Allen glorified twelve martyrs who were executed as traitors. Allen's martyrology was not drastically different from Alfield's but did offer further arguments as to the honesty in which the Crown operated these persecutions. However, one critical difference was that Allen's martyrology placed blame for the policy of persecution and execution directly upon Elizabeth. She had established a policy of extermination for English Catholicism and was determined to defend and promote this policy through treachery, dishonesty and slander. What had emerged within England with the Elizabethan persecutions was a "spectacle of heretical cruelty and Machiavellian practices, how by color of contrived treason and conspiracy the enemies of the Christian faith have shed their innocent blood to the Infinite shame of our nation." ${ }^{188}$ No longer was Elizabeth indirectly blamed for the actions and policies of her administration against Catholicism as Alfield had insisted. According to Allen, Elizabeth was guilty either of an

\footnotetext{
${ }^{187}$ Alfield, True Report, 15.

${ }^{188}$ William Allen, A Brief History of the Glorious Martyrdom of XII Reverend Priests, Executed...for the Confession and Defense of the Catholic Faith. But Under the False Pretense of Treason (NP, 1582), preface 2
} 
unwillingness to suppress the persecutions or of being a shrewd monarch directing and officiating the official policy of extermination. Whether Elizabeth could not control the persecutions or premeditated their actions, Allen presented the dishonest pursuit of Catholics based on treachery as the Crown's most despicable crime.

Allen pleaded with Elizabeth and her administrators to reveal the true policy of the Crown against English Catholics to England. Allen called for an end to manipulations, false labeling of the Catholics, and the deception of the English people. In depriving England of the "truth" of her persecutions, Alfield believed Elizabeth was also cheating English Catholicism. Elizabeth was guilty of violating an unwritten rule of martyrdom that defined the relationship of the persecutor and the persecuted, exemplified under Mary. Elizabeth was attempting to deny the right of martyrdom to the persecuted Christian sect. She was shrouding the truth, convincing England of an imagined danger of the Catholic missionaries, inventing a conspiracy against England and promoting persecution of Catholics for political reasons. Martyrdom was being removed from the process since a traitor had no other role, he was just that; religion had been removed from the equation. Allen presented Elizabeth and her administrators as the creators of this treason and originators of the crimes the Catholic were reported to have committed against the Crown.

Allen and English Catholics were being denied their role as religious martyrs.

Allen claimed that

If they had not used this matter in such an odd sort...into slanderous... and obloquy at crimes never thought of but only executed their new laws against them and made them away with religion without a doe, we should never have complained of any further iniquity or violence against us. ${ }^{189}$

${ }^{189}$ Allen, Glorious Martyrdom, 8. 
Allen did not resent the persecution of the Catholics, only the method used by the Crown to achieve the persecutions. If the Crown would only clarify to England that the Catholic priests were dying for their religion, not for a created disloyalty, the Catholics would have no further complaints. The formula for martyrdom would be correct. The Crown would be openly persecuting for religion and the Catholics dying based upon their religious convictions and faith. However, this was not the case, nor something that the Elizabethan government considered itself guilty of or was prepared to correct. Positions were already drawn. The Crown would continue to label the Catholics as traitors and execute these men for treason, while the Catholics would deny all charges, present the loyalty of the Catholic missionaries and glorify their dead as martyrs.

Alfield and Allen's purpose as martyrologists was to reveal the true nature of the persecution and display the Catholics that died as men whose character was opposite of that defined by the Crown. Since English Catholics were not in a position to prevent or deter the persecutions, Alfield and Allen could present the "truth" behind the Elizabethan persecutions. The reality and condemnable quality of the persecution was that it was a "most pitiful practice that ever was heard of to shed the innocent blood by face of public justice. Which is a thousand times before God more damnable and punishable by his divine power than if man's life was taken from him by murder." 190 The only worse offense committable against God would have been for martyrologists, such as Allen, to ignore this state of affairs, allow this slander never to be opposed, and sit idly by as God's martyrs were denied their place in the history of Christianity. ${ }^{191}$

\footnotetext{
${ }^{190}$ Allen, Glorious Martyrdom, preface 10.

${ }^{191}$ Ibid, preface 10.
} 
In refuting the "true" nature of the persecutions, Allen focused upon the interrogations and the evidence gathered from them that sealed the guilt of the Jesuits and Catholic priests. The interrogations were no different than the staged purpose of Elizabeth's persecutions. Allen described the Catholics facing torture and leading questions that were converted into evidence to define them as a traitor. The questions asked of the Catholics were presented as questions that, regardless of the answer, goaded out confessions of guilt. These questions pitted English Catholics' religious convictions against the their loyalty to the Queen. Questions focused on the Catholic missionaries allegiance to their religion. Was the Queen a lawful Queen to be obeyed by her subjects of the realm notwithstanding the Bull or any other papal Bulls? If the Pope does announce Elizabeth to be deprived of authority and an unlawful ruler and the Pope does invade the realm, which part or side are the subjects of England to take? ${ }^{192}$ Allen presented these questions as unfair, misleading and designed to prey upon the Catholics' answers and convert them into declarations of treason.

The confessions garnered from the interrogations were presented as evidence during the trials of the Jesuits and priests. Allen believed that this evidence was inadmissible and an instrument as dishonest and as the nature of the persecutions. It was anti-Catholic propaganda fed to the English subjects as absolute confessions of guilt. Elizabeth and the English subjects supportive of the persecutions viewed the Catholics undoubtedly as traitors. Allen, in his discussion of the interrogations, raised an important and somewhat obscured question of the Elizabethan persecutions.

Allen asked, if treason were the true cause of the priests' crimes, why would they not simply declare loyalty to the Crown and end the proceedings? When comparing ${ }^{192}$ Allen, Glorious Martyrdom, 25. 
treason and religion as convictions that motivated nonconformity against Royal decrees and possibly generated a resolve and steadfastness in the face of death, treason paled in comparison as motivation for facing death bravely. If treason was their true crime, why would these men not reverse allegiance, admit some instance of wrongdoing, and pledge loyalty to the Crown? Allen pointed out that this was not an option afforded the Catholic missionaries. In death these men were not choosing a fate chosen by traitors. By nature traitors were treacherous, they had no sense of allegiance, no sense of honor. Why would they not do the same to Catholicism? Allen's analysis pointed out many flaws within the Crown's claim of persecution for treason not religion. The martyrologies of Alfield and Allen created debate within the Elizabethan persecutions. Why were these Catholics being persecuted? Allen was successful in presenting an opposite argument to the Elizabethan royal proclamations and persecution.

What Alfield's and Allen's martyrologies left with their readers and England was an argument that Elizabeth and her administration were the criminals and villains of the persecutions. The government, because of the martyrological accounts, had failed to define itself absolutely as a defender of England rather than an oppressive persecutor. Allen presented this treachery committed by the Crown against England as proof that the Catholic missionaries would be "doubly glorified." 193 Controversy within Elizabethan England had arisen. The martyrs were used as examples that the Crown pursued a policy of extermination. Dillion states that the martyrologies provided a "banner, a rallying point of identification for the English Catholics, a symbol of their own adherence to the Catholic faith." 194 However, what resulted was that the intentions of the Crown and the

\footnotetext{
${ }^{193}$ Allen, Glorious Martyrdom, 25.

${ }^{194}$ Dillion, English Catholic Community, 8.
} 
Catholics of England were both in question. The evidence had been called tainted. After 1582 and the publication of Alfield's and Allen's martyrologies, the Crown would rely on anti-martyrologies, not only to defend its character as protector rather than persecutor but also to refute the Catholic martyrologies.

In April of 1582, the Crown responded to Alfield's and Allen's martyrologies and the controversy they had sparked over the persecutions. What was needed from the Crown was further reiteration of their charges, further validation of their charges of treason and above all refutation of the Catholics' claims to martyrdom. The 1582 proclamation challenged the Catholic claims of a state-initiated and sponsored deception of the English people, who were supporting an extermination of English Catholicism. It validated the persecutions based on treason and the internal threat that the Catholic missionaries and their Catholic flock represented to England. Once again the purposes of the Catholic missionaries was the question that would define the persecutions. The proclamation reiterated the Crown's stance that the priests intended

Not only to prepare sundry her Majesties subjects inclinable to disloyalty, to be apt to give aid to foreign invasion and to stir rebellion within the same: but also (that most perilous) to deprive her Majesty (under whom, and by whose provident government with God's assistance, these realms have been so long and so happily kept and continued in great plenty, peace, and security of her life, Crown, and dignity). ${ }^{195}$

This proclamation not only portrayed the Catholic missionaries as traitors, but also described those who protected them, harbored them, and wrote in defense of them as ungrateful subjects of England. In aiding these "traitors," these English subjects supported and defended the Catholics without respective consideration for the twenty years of peace and stability that Elizabeth had brought to England.

\footnotetext{
${ }^{195}$ Royal Proclamation of April 1, 1582 “To Denounce Jesuit Traitors" (NP, 1582), 2.
} 
What initiated this charge against English subjects previously separated from the fray was the appearance and spread of Catholic martyrologies. The proclamation defined them as "letters, libels, pamphlets, and books both written and printed, falsely, seditiously and traitorously given out, that the said most horrible traitors, were without just cause condemned and executed."196 Apparently these martyrologies had some, albeit minor, effect on the acceptance of the persecutions. The Crown was warranted to act quickly and decisively in response. Criminals were being glorified, their accounts as martyrs being spread. Everything proposed by the Crown from 1580 was threatened to be undone. The martyrologies intended to reverse the vilification of the persecutions and, instead, replace it with the glorification of the men the Crown identified as traitors. The 1582 proclamation reminded England that evidence was collected during interrogations that revealed these Jesuits and Catholic priests as "traitors to her Majesty, her Crown and Realm." 197 The Crown made it known that these persecutions were legal, despite the Catholic claims of deceptions and false intentions. The letter of the law was being observed, for the Jesuits and Catholics accused of heresy were "lawfully, publicly, and orderly indicted, arraigned condemned and executed for divers treason."198 What is apparent from the Proclamation of April 1582 is that part of England did not accept the persecutions as the Crown described, and that not all accepted the threat of treason and rebellion, the backbone of the persecutions.

The Marian process of persecution, followed by martyrdom, followed by martyrologies and defended against by anti-martyrologies was revived within the Elizabethan persecutions. The proclamations of 1581 explained the charges that would

\footnotetext{
${ }^{196}$ Royal Proclamation, "Jeuits," 2.

${ }^{197}$ Ibid, 2.

${ }^{198}$ Ibid, 1.
} 
soon be applied to the Jesuits and Catholics. The martyrologies that followed honored the executed as martyrs, by deconstructing and refuting the charges presented by the Crown. The proclamation of April 1582 began the Crown's anti-martyrological defense, only to be supported by anti-martyrological writings from outside of the Elizabethan administration. Young describes the appearance of anti-martyrological writings after the Catholic martyrologies, saying "Protestant writers began not only to answer these writings, but more importantly to make counter charges of their own." 199 William Fulke wrote two anti-martyrologies in 1581 and 1582 , which attempted to recapture the Catholic anxiety that drove the persecutions and to refute Catholics' construction of their priest as martyrs.

Fulke, a Puritan and contemporary of Champion at a London school, described the martyrologies as unfounded tales of woe, written by criminals with the purpose of vilifying the Crown. ${ }^{200}$ These were tales written to incite sympathy, either from English Protestants or English subjects not affiliated with Elizabethan Protestantism or Catholicism. They were pleas of empathy, designed to end what they presented as unjust suffering. Fulke summarized them as tales of

Many great gentlemen of worship...imprisoned for their conscience and religion of late, so many good houses broken up and so many householders dispersed and fled away...so many children bereft of their parents...such shutting up in prisons, such pitiful abiding hunger, thirst, and cold in prisons... all of this for different opinions in religion, a misery not accustomed to fall in our fathers days upon that noble realm. ${ }^{201}$

Fulke was attacking the martyrologies with a bit of sarcasm. He reminded England that persecution and the destruction of family was once visited upon their families. In

\footnotetext{
${ }^{199}$ Young, Jr., "Definitions of Treason," 680.

${ }^{200}$ Bossy, Catholic Community, 15.

${ }^{201}$ William Fulke, A Brief Confutation, 1.
} 
comparison to Marian anti-martyrologists, Fulke was reminding England that no sympathy should be given to the persecuted, no empathy granted and no remorse shown in supporting the persecution's actions.

Fulke described the blame for the persecutions as resting not on the Crown, as the Catholic martyrologies proposed, but on the traitors who chose death. Like the antimartyrologists of Marian England, Fulke found it inexplicable that English Catholics would choose death over conformity. To Fulke, this choice in itself was a form of disloyalty. The Queen's policies and decrees were being denied, assimilation was offered but rejected. Nonconformity was inexcusable and unalterable evidence that Catholic loyalty rested with the Pope and treason against England. This process of refutation was very similar to that followed by the Marian anti-martyrologies. Anti-martyrologists would focus on the qualities and evidence used by the martyrologies to construct martyrs. As discussed earlier, whereas the act of dying well was promoted as a quality of the Protestant martyrs, the Catholics all displayed loyalty to the Queen during their last moments. Anti-martyrologies were written to counter the qualities displayed as commendable. Fulke described the Jesuits and Catholic priests as facing an easy decision: deny the Pope and their Catholic mission of rebellion and side with their loyalty to England. However, treachery proved a more powerful motive of the Catholic missionaries than loyalty. Fulke insisted that the Jesuits and priests were guilty of persistent separation from English society, recusancy, and the inability to acknowledge any law of England that defied their Catholic laws. ${ }^{202}$

Once again the argument of the Crown and Elizabethan anti-martyrologists was that the Catholics hid their treasonous purposes in their ministerial mission. Fulke

\footnotetext{
${ }^{202}$ William Fulke, Scandalous libel, 1.
} 
presented religion as a "cloak to cover whatever by secret conspiracies against the state." ${ }^{203}$ Religion was the ruse, an excuse to live disloyally in England, while planning and plotting to undermine the royal authority and the religious peace. The true mission, the principle presented by the Crown as the purpose of the persecutions was to eventually conquer and hand over power to the papal and foreign domination. No one Elizabethan writer did more to promote and defend the Crown's cry of an international monolithic Catholic threat in England than Anthony Munday.

Munday claimed first-hand knowledge of the role that the Jesuits and Catholic priests would play in the Catholic conquest of England if not prevented by the Crown. Munday had played the part of informant in the arrest and trial of an unnamed Catholic missionary. In his Brief Answer in 1582, Munday argued the importance of informers within England in stepping forward and revealing Catholic threats and bringing justice to radical Catholic cells. While Munday did glorify the role of informant, his Brief Answer also revealed that an undying loyalty and support for the actions of the Crown did not exist within Elizabethan England, especially toward informers who relished in their role as convectors of the Catholic priests.

Munday's Brief Answer was a plea to Elizabeth to suppress the personal attacks directed at Munday by fellow Englishmen. Munday's plea to Elizabeth dispels any notion of unanimous approval of the persecutions and suggests that there existed opposition to the role of informant, the same role vilified by Alfield in True Report. The question must be proposed: how deeply did the Catholic martyrologies resonate within the Protestant dominated Elizabethan England? Munday's plea also incites the question of whether sympathies were provoked by the martyrologies from outside the Catholic

\footnotetext{
${ }^{203}$ Fulke, Scandelous Libel, 3.
} 
community. It seems so in Munday's case, for he called upon an old saying to describe his plight within England, saying "A man is no worse esteemed, than in his own country." 204 Despite the Crown's and anti-martyrologists' attempts to align all of England behind the persecutions and the presented argument that England was susceptible to a revolt from within led by the Jesuits and Catholic priests, these arguments proved distasteful to many.

Munday also finished a narrative in 1582 that was a description of the intensity of Catholicism's reach within England and Catholicism's crusade against Elizabeth. Munday's English Roman Life was a travel narrative of his and his companion's adventures in Europe. In it, Munday revealed the real depth and reach of the international Catholic conspiracy against England and the role that Englishmen played in it. Munday artistically painted the Catholic loyalty to the Pope and their unwavering mission to conquer and change the religious landscape of England. If an anxiety over English Catholicism was only considered paranoia and illegitimate before one read Munday's account, after reading and accepting Munday's adventure one would be prepared to immediately move family and friends to a defensive stronghold in England. It is difficult to picture an English subject, as dedicated as Munday, setting course for the continent and traveling into the lion's den that Rome represented. But Munday justified his travels as motivated by an adventurer's spirit. He wrote that he and his companion set out on their journey "because we thought, if we could go to Rome, and return safely again into England, we should accomplish a great matter...the voyage so dangerous.," ${ }^{\text {,205 }}$ What an

\footnotetext{
${ }^{204}$ Anthony Munday, A Brief Answer, 3.

${ }^{205}$ Anthony Munday, The English Roman Life, 5.
} 
adventure it proved for its reader, but one that was enough to cast an Englishmen into a permanent state of paranoia.

Once upon the continent at Amiens, Munday and his companion sought out an Englishman for lodging. They settled, for the night, with an English priest. After exchanging pleasantries, the priest urged Munday and his fellow traveler to take council with the Pope and aid in slandering their Queen. After their night's stay and as goodbyes were being said, the priest further "manifested his treason toward England" and attempted to enlist Munday and his friend "to be traitors to their own Princess, to shorten her life." ${ }^{206}$ Out of fear for their lives, Munday and his companion accepted a letter from the English priest directing them to Rhiemes and an English seminary. Although Munday and his companion were traveling toward Rhiemes with a letter of a traitor and with the purpose of becoming priests, this remained an adventure or a fact-finding mission. Their loyalty was never in question, for on the way they remembered the "true and undoubted religion, used in our own country."207

After a brief education at the seminary of Rhiemes, the priest urged Munday and his companion to travel to Paris for what appeared to be further indoctrination into the Catholic conspiracy against England. Traveling to Paris they met other Englishmen who treated them courteously and talked of an army that would shortly arrive in Ireland. This army consisted of Spaniards and would "make England quake" and there were "more Englishmen gone to the Pope for more aid." ${ }^{208}$ These Englishmen urged Munday to travel to Rome and seek council with the Pope. Munday and his companion dutifully followed instruction and set course for Italy. The arrived in England and were frightened

\footnotetext{
${ }^{206}$ Munday, Roman Life, 5.

${ }^{207}$ Ibid, 6-7.

${ }^{208}$ Ibid, 8.
} 
to find more Englishmen, all rallied to the cause of conquering England for the Pope. Munday was pained to "hear the horrible treasons invented against her Majesty and this realm, and so greedily followed by our own countrymen."209

Munday's time spent in Rome further validated his worry for England. Englishmen and Catholics were united in a crusade to rid England of Elizabeth and its religious peace. In concluding the narrative, Munday reminded his readers to fully comprehend the events they had read and the threat English Catholics presented. If this much danger existed from Englishmen outside of the realm of England, imagine the threat from those within. Munday wrote, "You have heard here in, how at sundry places and by several speeches, there was a general agreement of treason, expected and daily looked for to harm of our gracious sovereign, and hurt of her whole realm."210 Paranoia was the purpose of this narrative, whether the treason of English Catholics was real or imagined. Munday reinforced to his readers that a conspiracy existed in England, one directed by Rome that intended to enlist all Catholics in its cause, whether they were English or not.

Where Munday's narrative reinforced the Crown's position on the existence and threat of an international Catholic conspiracy, William Burghley Cecil's defense of the persecutions in 1583 solidified the Crown's position against martyrdom. Cecil represented the first insider of the Elizabethan administration to speak out on the persecutions and the Catholic use of martyrdom. Cecil's Execution of Justice further clarified the Crown's position on treason, but also refuted much of the material used by Alfield and Allen to make the Jesuits and Catholics into martyrs. Cecil, the chief councilor of Elizabeth's administration, was making a blanket statement, an absolute

\footnotetext{
${ }^{209}$ Munday, Roman Life, 10.

${ }^{210}$ Ibid, 12.
} 
refutation directly from the administrative mechanism. Cecil's Execution of Justice attempted to terminate any sympathies projected toward the English Catholics as their construction as martyrs.

Cecil's refutations and defenses of the Elizabethan persecutions mirrored the methods used by the Marian anti-martyrologists. Whereas the Marian anti-martyrologies focused on the methods and qualities applied by Protestant martyrologies for their refutations, Cecil, similarly, focused on the evidence used by Catholic martyrologies to prove that the persecutions were motivated by religion. Cecil directed his assault on this evidence, presenting to England as grossly exaggerated and embellished. In the account of Alexander Bryan, Alfield described the priest as suffering torture, thirst and hunger while a prisoner of the Crown. Cecil revealed to his readers that whatever Bryan suffered, and his suffering was very little, was suffered "willfully and of extreme obstinacy against the mind and liking of those who dealt with him." ${ }^{211}$ As to Champion's extreme suffering described by the martyrologies, Cecil explained that his prison stay was "charitably used" and he was "never so racked" as detailed in the martyrologies. ${ }^{212}$

What Cecil set out to prove was that these martyrologies were purely propaganda, distributed in order to vilify the Crown and generate support for the treason the Catholic's pursued. The martyrologies were embellishments on the minor truths contained within the Catholic martyrologies. For one, Cecil wrote that the "forms of torture in their sovereignty or rigor, of execution, have not been such in such manner performed as the slanders and seditious libelers have slanderously and seditiously published." ${ }^{213}$ These accounts were false and Cecil urged England to consider the type of people they were

\footnotetext{
${ }^{211}$ William Burghley Cecil, The Execution of Justice, 2.

212 Ibid, 2 .

${ }^{213}$ Ibid, 2.
} 
dealing with. These were criminals guilty of deceiving England with a ministry founded on treason. They were criminals arrested, tried, and executed for a long list of abuses against the Crown, and the martyrologies that glorified these actions were merely Catholic attempts to remove the criminal aspect from the executed.

Cecil's main purpose was to emphasize that Catholic martyrdom or martyr making would not be successful in Elizabethan England. Cecil understood the power and use of martyrdom as a tool of resistance and promotion. He wrote that

It hath in all ages and in all countries, a common usage of all offenders for the most part both great and small, to make defense of the lewd and unlawful facts by untruths and by coloring their deeds with the pretense of some other causes of contrary operations or effects: to the intent not only to avoid punishment or shame, but continue, uphold and prosecute their wicked attempts to the full satisfactions of their disordered and malicious appetites. ${ }^{214}$

Cecil pointed out that history had proven that those guilty of crimes against the state, whether treason or heresy, used their plight and persecutions as examples of royal mistreatment and a cause for martyrdom. The Catholic martyrologists, who had aligned themselves on the side of treason, were also guilty of promoting treason by spreading "untrue rumors and slanders to make her merciful government disliked under false pretenses, and rumors of sharpness and cruelty, to those against whom nothing can be cruel, and yet whom nothing hath been done, but gentle and merciful."215 The martyrologies were falsifications of the persecutions, claiming religion instead of treason and presenting the Catholics as noble victims rather than despicable traitors.

Martyrdom was yet another Catholic attempt to conquer England. However, martyrdom would not work for men who professed loyalty, yet chose death over their

\footnotetext{
${ }^{214}$ Cecil, Execution of Justice, 1.

${ }^{215}$ Ibid, 4.
} 
nation and Queen. Upon death these men cried "out that they were true subjects and did and would obey and serve her Majesty."216 It was impossible for Englishmen to have a double loyalty, one to a religion and another to a Queen and state threatened by this religion. Loyalty was singular; it applied either to the realm or the papacy. There were no grey areas in England for Cecil and the Crown. The anti-martyrologies were written to remove martyrdom from the Elizabethan persecutions and Covington comments, that for such writers

it was necessary to insist that the Catholic victim had been executed---indeed, been cut apart in a specific, traditionally significant way---solely because of his treason in order for them to seize the discourse and counter any claims of martyrdom or even injustice on the state's part. ${ }^{217}$

The anti-martyrologies presented evidence that the martyrologies that vilified England and attempted to turn public opinion were yet another method applied by Catholics to further infiltrate English society with a Catholicism that threatened the peace and safety of England.

Approximately 125 Catholic priests and sixty reuscents were executed as traitors under the reign of Elizabeth, primarily in the $1580 \mathrm{~s}$ as the threat of foreign Catholicism circled England. ${ }^{218}$ Arguments concerning the Elizabethan persecutions are based on which account of the persecutions is held as true: the anti-martyrology or martyrology. Anti-martyrological evidence presents the Jesuits and Catholic missionaries as a serious threat and with intentions to stir rebellion against the Queen. Martyrological evidence presents the intentions of the Jesuits and Catholic missionaries as pure, only to be persecuted by a vengeful Queen. Despite the controversy, Elizabethan, as did the Marian,

\footnotetext{
${ }^{216}$ Cecil, Execution of Justice, 4.

${ }^{217}$ Covington, Trail of Martyrdom, 196.

${ }^{218}$ Ibid, 161.
} 
administration was successful in containing martyrdom. Both queens relied on documents and written explanations of the persecutions to control and maintain a public opinion that was supportive of the persecutions and Elizabeth's more so than Mary's. But what Mary and Elizabeth proved, with support of sympathetic writers and antimartyrologies, was that it was possible for a government to persecute, and continue to persecute despite martyrdom and the power its carried. Although martyrdom could not be prevented or completely countered, it could be contained, explained and defended against in a way that allowed it to remain, but not draw the sympathy and support that the persecuted needed in order to end the persecutions. 


\section{CONCLUSIONS}

A focus comparing and discussing the Marian and Elizabethan persecutions vividly presents the ways in which persecuting governments and subjects aligned with the persecutions explained nonconformity and death in reformation England. The intended audience for these primary documents was the subjects of England--a people often characterized in the several martyrologies and the anti-martyrologies of reformation England as ignorant, easily misled, culpable and not particularly loyal in their allegance to religion or politics. It was this complete disregard of the English people and the instability of their public opinion that the Marian and Elizabethan pro-persecution writers directed their work. The reign of both queens proves that the persecutions had to be introduced and discussed in a way that would create and hold public support. The martyrologies that followed planned to take advantage of this belief in an easily swayed England by documenting, glorifying and distributing the actions of the Protestant and Catholic martyrs.

The power these martyrologies wielded was not in the fact that their accounts were embellished, but that English subjects untouched by the persecutions, unaffected by pro-persecution writings, or unaffected by the evangelical moments of executions were reached and granted accounts that venerated the executed. The anti-martyrologies written in response to martyrdom were yet another bid from the Crown for the sympathies and 
public support of England. This was the cycle of persecuting created within reformation England. At every stage, despite monarchial superiority, the English people were courted with documents and accounts from the persecutors and the persecuted. Support was being vied for and battled over. Although neither Mary nor Elizabeth ever faced rebellion or insurrection based upon their policies of persecution and the majority of England remained supportive of the persecutions, documents were required to counter martyrdom.

Marian and Elizabethan writers and anti-martyrologies approached the persecutions, public opinion and martyrdom in the same way. The persecutions were first introduced, explained, and outlined. It was described who would be the persecuted, why they were persecuted, the role of the Crown and all of England in these persecutions, and ultimately set the stage for the martyrologies that followed. As martyrdom was claimed by the persecuted, the Marian writers and the Elizabethan Crown, aided by secular writers, directly attacked the Protestant and Catholic martyrs. They did this in similar ways. As observed in Foxe's Acts and Monuments and the Catholic martyrologies of Elizabeth, martyrologists relied on basic principles, methods and fundamentals in constructing their dead as martyrs. Anti-martyrologists attacked these methods and basic martyrdom qualities in hopes of reversing the glory that had been bestowed upon the executed. While both kinds of writers wrote in the pursuit of public opinion, what they produced was also to be considered an absolute and definitive history of the times.

"Truth" was ultimately what was at stake and neither the anti-martyrological or martyrological writers assumed that the other side of the conflict would prevail. Foxe's martyrology came to dominate the history of the Marian persecutions, to the extent that anti-martyrologies are seldom mentioned. The efficiency of the Elizabethan 
administrative machine shrouds the fact that 125 Catholics were executed under her reign. The most important topic is what was the true nature of the persecutions: religious or political. When history was written, until recently, discussing the Elizabethan persecutions, one's perception of Elizabeth and her persecutions was based upon which account of the persecutions one held as true: the anti-martyrologies or martyrologies. Basically, not much has changed from Elizabethan England.

History, or at least the perceptions of the persecutions, is based upon which accounts are taken as the accurate descriptions of the times. Was the Crown protecting the stability of the nation with its persecutions, or brutally attempting to destroy a powerless minority? Because of Elizabeth's accession and Foxe's martyrology, Mary is painted as the ruthless persecutor. Because of the efforts of the Elizabethan Crown and Elizabethan anti-martyrologists, Elizabeth is portrayed as a monarch successful in maintaining a peace and stability in England. Mary's persecutions are deemed a failure and Elizabeth's are deemed successful, pragmatic and efficient control of her realm. In reality, and after observing the ways in which the Crown supported and defended its persecutions, how different are the Marian and Elizabethan persecutions? Granted, they persecuted for different reason, but ultimately, religion and politics were overshadowed by the presence of nonconformity and the assertion of monarchial superiority to suppress it.

Questions still remain over the Marian and Elizabethan persecutions--questions that remain unanswered by the primary sources analyzed in this paper. One obvious question is why were no anti-martyrologies produced after 1556 in Marian England? In 1556, as Mile Huggarde penned the last Marian anti-martyrology, the Crown and England 
had yet to face Mary's "grass roots" extension of the persecutions. Another glaring question when comparing the queens' persecutions is based upon the defenses that were issued directly from the Crown. Why did Mary's administration not offer defenses for its persecutions or anti-martyrologies as the Elizabethan administration had? Was it because the persecutions were carried out for religious purposes rather than political? Mary's persecution, one that took more lives than any in English history, were not defended from the source, the most identifiable promoter and pursuer of the persecutions. If the Crown did not issue defenses of the persecutions and anti-martyrologies because this was a Church operated and administrated persecution, then where are the public defenses issued from the Church?

Questions that arise over the Elizabethan persecutions would offer more insight into the atmosphere of Elizabethan England at the time of the persecutions. Elizabeth's reign was complex. Eventually, Elizabeth would rule over numerous, competing religious factions: Anglican Protestants, Puritans, Presbyterians, and Catholics. The effect of these different religious groups on Elizabethan policy and the Elizabethan persecutions is beyond the scope of this project. But, the effect of these competing religious groups on Elizabethan policy would provide many answers. Elizabeth's Protestant kingdom was a collection of Protestants sects, all calling for changes in the Anglican Church that would correspond with what they considered the "true" Church doctrine. Therefore in the 1570 s and 1580 s, Elizabeth's concern was not only the threat of foreign Catholicism, but also the threat of the more radical Puritan factions of separating from the Anglican Church. The one thing that all these factions within Elizabethan England could agree on was their hatred and fear of Catholicism. Then the 
question arises, how did the Elizabethan persecutions affect the relationship of the Crown and the Puritan and Presbyterian groups? Did it create a common ground and a common enemy at a time when the threat of Puritan and Presbyterian separation was a reality? This is merely speculation, but the consequences of the competing Protestants factions would be important in observing how and why Elizabethan policy was created? Were their any underlying motives for the persecutions, aside from a fear of Catholicism? (19 $^{219}$

Although these questions remain unanswered or left obscured by the primary sources of the Marian and Elizabethan persecutions, what is shown is the ways in which the Crown prepared the nation for persecutions and combated martyrdom. The argument over "true" and "false" martyrs has become timeless, directly due to the controversial battle between martyrologies and anti-martyrologies. Religious convictions and political loyalty were changed based on the anti-martyrological and martyrological accounts. Histories were written based on the anti-martyrological and martyrological accounts, histories that intended to permanently and decidedly place the label of criminal or brutal persecutor upon the other side of the conflict. This was the importance of antimartyrologies within the process of persecution. They were the final defenses; martyrdom could not be prevented or overturned, but it and public opinion could be contained with anti-martyrologies.

\footnotetext{
${ }^{219}$ Elliot Rose, Case and Conscious, 11.
} 


\section{REFERENCES}

Marian Primary: All primary sources were taken from the English Short Title Catalogue: 1475$\underline{1700 .}$

Barlow, John. Dialogue. NP, 1555.

Beard, Richard. A Godly Psalm of Mary Queene. NP, 1553.

Gwynethe, John. A Declaration of State Wherein All Heretics Do Lead Their Lives. NP, 1554.

Huggarde, Miles. The Displaying of the Protestants... with a Description of Their Abuses of Late Frequented. NP, 1556.

Ponet, John. A Short Treatise of Politic Power. Winchester: NP, 1556.

Proctor, John. The History of Wyatt's Rebellion. London: R. Cally, 1554.

Stapleton, Thomas. A Fortress of Faith. London: Scholar Press, 1565.

\section{Elizabethan Primary}

Alfield, Thomas. A True Report on the Death and Martyrdom of M. Champion Jesuit, and M. Sherwin and M. Bryan at Tiborne, the $1^{\text {st }}$ of December 1581. NP, 1582.

Allen, William. An Apology and True Declaration of the Institution and Endeavors of the Two English Colleges. Mounts Press, 1581. 
A Brief History of the Glorious Martyrdom of XII Reverend Priests, Executed...for Catholicism and Defense of the Catholic Faith. But Under the False Pretense of Treason. NP, 1582.

Cecil Burghley, William. The Execution of Justice in England for the Maintenance of Public and Christian Peace, Against Certain Stirrers of Sedition, and Adherents, to the Traitors and Enemies of the Realm. London: NP, 1583.

Foxe, John. Acts and Monuments Vol. One. NP, 1563.

Fulke, William. A Confutation of a Popish and Scandalous Libel, in Form of an Apology: Given Out Unto the Court and Spread About in Diverse Other Places of the Realm. London: John Kingston, ND.

Munday, Anthony. A Brief Answer Made Unto Two Seditious Pamphlets...Containing a Defense of E. Champion and His Compliances. London: John Charlewood, 1582.

. The English Roman Life: The Lives of Englishmen at Rome: The Orders of the English Seminaries...the Banishing of the Englishmen Out of Rome. John Charlewood, 1582.

Royal Proclamation of July 15, 1580. Against Rebels. Christopher Baker, 1580.

Royal Proclamation of January 10, 1581. A Proclamation for Revocation of Students From Beyond the Seas, and Against the Retaining of Jesuits. NP, 1581.

Royal Proclamation of April 1, 1582. To Denounce Jesuit Traitors. NP, 1582.

\section{Secondary}

Atteridge, A. Hilliard, The Elizabethan Persecution: Did its Victims Suffer for the Old Faith of England or For Treason? London: Harding and More LTD, 1928. 
Bade, Dom Reverend, ed. The English Martyrs: Papers From the Summer School of Catholic Studies Held at Cambridge, July 28-August 6, 1928. Cambridge: Harder Book Co., 1928.

Betteridge, Thomas. Tudor Histories of the English Reformation, 1530-83. Ashgate: Aldorshat, 1999.

Bossy, John. The English Catholic Community: 1570-1850. London: Darton, Longman and Todd, 1975.

Bridgen, Susan. New Worlds, Lost Worlds: The Rule of the Tudors 1485-1603. New York, Viking Press, 2000.

Collison, Patrick and John Craig, eds. The Reformation in English Towns, 1500-1640. London: MacMillian Press LTD, 1998.

Covington, Sarah. The Trail of Martyrdom: Persecution and Resistance in Sixteenth Century England. Notre Dame: University of Notre Dame Press, 2003.

Dillon, Anne. The Construction of Martyrdom in the English Catholic Community, 1535-1603. Burlington: Ashgate Publishing, 2002.

Greaves, Richard L. "Concepts of Political Obedience in Late Tudor England: Conflicting Perspectives" The Journal of British Studies. Vol.22, No. 1, Autumn, 1982.

Gregory, Brad S. Salvation at Stake: Christian Martyrdom in Early Modern Europe. Cambridge: Harvard University Press, 1999.

Haigh, Christopher. "The Continuity of Catholicism in the English Reformation" Past and Present. No.93, November, 1981.

Jordan, W.K. The Development of Religious Toleration in England...to the Death of Queen Elizabeth. Cambridge: Harvard University Press, 1932. 
Kelley, Donald R. "Martyrs, Myths, and the Massacres: The Background of St. Bartholomew," The American Historical Review. Vol. 77, No. 5, December, 1972.

Knott, John R. Discourse of Martyrdom in English Literature, 1563-1694. Cambridge: Cambridge University Press, 1993.

MacCaffery, Wallace T. Queen Elizabeth and the Making of Policy. Princeton: Princeton University Press, 1982.

MacCulloch, Dairmaid. The Boy King: Edward VI and the Protestant Reformation. New York: Palgrave, 1999.

McCoog, Thomas M. SJ. The Society of Jesus in Ireland, Scotland and England, 1541, 1588. New York: E.J. Brill, 1996.

Metzger, Marcia Lee. "Controversy and 'Correctness:' English Chronicles and the Chroniclers, 1553-1568," Sixteenth Century Journal. Vol. 27, No.2, Summer, 1996.

Morey, Adrian. The Catholic Subjects of Elizabeth I. Totowa: Rowan and Littlefield, 1978.

Pettegree, Andrew. Marian Protestantism (Six Studies). London: Scholar Press, 1996.

Pritchard, Arnold. Catholic Loyalism in Elizabethan England. Chapel Hill: University of North Carolina Press, 1979.

Questier, Michael. "Practical Antipapistry during the Reign of Elizabeth I," The Journal of British Studies. Vol. 36, No. 4, October, 1997.

Ridley, Jasper. Bloody Mary's Martyrs: The Story of England's Terror. New York: Carroll and Graf Publishers, 2001.

Robinson, William B. "The National Significance of Wyatt's Rebellion in Surrey," The Historical Journal. Vol.30, No. 4, December, 1987. 
Rose, Elliot. Case and Consciousness: Alternatives Open to Recusants and Puritans Under Elizabeth I and James I. London: Cambridge University Press, 1975.

Thomas, D. Aneurin, ed. The Welsh Elizabethan Catholic Martyrs: The Trail Documents of Saint Richard Gwyn and of the Venerable William Davies. Candiff: University of Wales Press, 1971.

Wiatt, William H. "The Lost History of Wyatt's Rebellion," Renaissance News. Vol. 15, No. 2 Summer, 1962.

Wood, Diane, ed. Martyrs and Martyrologies: Papers Read at the 1992 Summer Meeting and the 1993 Meeting of the Ecclesiastical History Society. Blackwell Publishers: Oxford, 1993.

Youngs, Jr., Frederick. "Definitions of Treason in an Elizabethan Proclamation," The Historical Journa., Vol. 14, No. 4, December, 1971. 


\title{
CIRRICULUM VITAE
}

NAME: $\quad$ Mitchell Scott

ADDRESS: 1200 East Broadway Apt\#6

Louisville, KY 40204

DOB: $\quad$ Princeton, Kentucky 42445

\author{
EDUCATION \\ \& TRAINING: $\quad$ B.A., History \\ Murray State University \\ 1997-2002
}

